\title{
In vitro screening of technical lignins to determine their potential as hay preservatives
}

\author{
D. C. Reyes, ${ }^{1}$ S. L. Annis, ${ }^{2}$ S. A. Rivera, ${ }^{1}$ A. Y. Leon-Tinoco,,${ }^{1}$ C. Wu, ${ }^{3}$ L. B. Perkins, ${ }^{4}$ J. J. Perry, ${ }^{4}$ Z. X. Ma, ${ }^{5,6}$ \\ C. W. Knight, ${ }^{7}$ M. S. Castillo, ${ }^{8}$ and J. J. Romero ${ }^{1 *}$ \\ ${ }^{1}$ Animal and Veterinary Sciences, University of Maine, Orono 04469 \\ ${ }^{2}$ School of Biology and Ecology, University of Maine, Orono 04469 \\ ${ }^{3}$ Department of Animal and Food Sciences, University of Delaware, Newark 19716 \\ ${ }^{4}$ Food Science and Human Nutrition, School of Food and Agriculture, University of Maine, Orono 04469 \\ ${ }^{5}$ Emerging Pathogens Institute, University of Florida, Gainesville 32608 \\ ${ }^{6}$ Department of Animal Science, University of Florida, Gainesville 32608 \\ ${ }^{7}$ University of Maine Cooperative Extension, Orono 04469 \\ ${ }^{8}$ Department of Crop and Soil Science, North Carolina State University, Raleigh 27607
}

\section{ABSTRACT}

Our objectives were to evaluate technical lignins for their antifungal properties against 3 molds and 1 yeast causing hay spoilage, and their ability to preserve ground high-moisture alfalfa hay nutritive value in vitro. In experiment 1,8 technical lignins and propionic acid (PRP; positive control) were tested at a dose of $40 \mathrm{mg} / \mathrm{mL}$. The experiment had a randomized complete block design (RCBD, 4 runs) and a factorial arrangement of 3 molds $\times 10$ additives (ADV). The effects of the ADV on yeast were evaluated separately with a RCBD. Sodium lignosulfonate $(\mathrm{NaL})$ and PRP were the only treatments with $100 \pm 2.8 \%$ inhibition of fungi. In experiment 2 , the minimum inhibitory concentration (MIC) for selected lignins and PRP were determined. At $\mathrm{pH} 4, \mathrm{NaL}$ had the lowest MIC across the molds $(20-33.3 \mathrm{mg} / \mathrm{mL})$ and magnesium lignosulfonate (MgL) for the yeast (26.7) among the lignins. However, PRP had MIC values that were several-fold lower across all fungi (1.25-3.33). In experiment 3, a RCBD (5 blocks) with a 3 (ADV; NaL, MgL, and PRP) $\times 4$ (doses: $0,0.5,1$, and $3 \% \mathrm{wt} / \mathrm{wt}$ fresh basis) factorial arrangement of treatments was used to evaluate the preservative effects of ADV in ground high-moisture alfalfa hay inoculated with a mixture of the fungi previously tested and incubated under aerobic conditions in vitro. After 15 d, relative to untreated hay (14.9), dry matter (DM) losses were lessened by doses as low as $1 \%$ for $\mathrm{NaL}(3.39)$ and $0.5 \%$ for PRP $(0.81 \pm 0.77 \%)$. The mold count was reduced in both NaL at $3 \%$ (3.92) and PRP as low as $0.5 \%$ (3.94) relative to untreated hay $(7.76 \pm 0.55 \log \mathrm{cfu} /$ fresh g). Consequently, sugars were

Received October 17, 2019

Accepted March 2, 2020.

*Corresponding author: juan.romero@maine.edu best preserved by NaL at $3 \%(10.1)$ and $\mathrm{PRP}$ as low as $0.5 \%(10.5)$ versus untreated $(7.99 \pm 0.283 \% \mathrm{DM})$, while keeping neutral detergent fiber values lower in NaL (45.9) and PRP-treated (45.1) hays at the same doses, respectively, relative to untreated $(49.7 \pm 0.66 \%$ DM). Hay DM digestibility was increased by doses as low as $3 \%$ for $\mathrm{NaL}$ (67.5), $1 \% \mathrm{MgL}(67.0)$, and $0.5 \%$ PRP (68.5) versus untreated hay $(61.8 \pm 0.77 \%)$. The lowest doses increasing neutral detergent fiber digestibility relative to untreated hay (23.3) were $0.5 \%$ for MgL and PRP (30.5 and 30.1, respectively) and $1 \%$ for $\mathrm{NaL}(30.7 \pm 1.09 \% \mathrm{DM})$. Across technical lignins, NaL showed the most promise as a potential hay preservative. However, its effects were limited compared with PRP at equivalent doses. Despite not having an effect on preservation, $\mathrm{MgL}$ improved $\mathrm{DM}$ digestibility by stimulating neutral detergent fiber digestibility. This study warrants further development of $\mathrm{NaL}$ under field conditions.

Key words: hay preservation, technical lignin, ruminal digestibility

\section{INTRODUCTION}

In the United States, hay is the predominant forage conservation method (NASS, 2019a), the third most valuable crop ( $\$ 17$ billion/yr), and second in harvested acres (53 million acres, NASS, 2019b). The main goal in haymaking is to decrease the moisture concentration to less than 15 to $20 \%$ in no more than 3 to $5 \mathrm{~d}$ so most of the forage crop nutrient yield can be stored long term (Rees, 1982). Nutrient losses during hay harvest and storage are interdependent. During harvest, field losses can occur due to increased leaf fragility as moisture decreases, especially below 20\%. However, if hay is baled above 15 to $20 \%$ moisture, extensive microbial spoilage will occur during storage and result in 
a significant decline in nutritive value (Coblentz and Hoffman, 2009) and increased DM losses (up to 30\%; Ball et al., 1998). Baleage has been considered as an alternative for producers to store wet hay (Shinners, 2010). However, baled hay is more marketable, needs less equipment, and has fewer plastic disposal issues. Thus, there is a great need for preservatives that can allow for baling hay above $20 \%$ moisture so both field and storage losses can be reduced. Currently, propionic acid-based products are the most used hay preservatives, but their efficacy in preventing spontaneous heating is limited to 6 mo (Coblentz et al., 2013). Therefore, more effective and inexpensive hay preservatives are needed to improve the efficiency of hay production.

Technical lignins are byproducts of paper mills and approximately 50 million $\mathrm{Mg} / \mathrm{yr}$ are produced worldwide, but only $2 \%$ are commercialized with the rest being incinerated (Gosselink et al., 2004). Certain technical lignin types, such as kraft lignins and lignosulfonates, have reported antibacterial (Dong et al., 2011), antifungal (Jha and Kumar, 2018), antiviral (Gordts et al., 2015), and prebiotic effects (Flickinger et al., 1998). In fact, lignosulfonates have been long used to increase soybean protein bypass in the rumen (Borucki Castro et al., 2007) and as feed binders (Corey et al., 2014). These properties could be adapted to prevent hay spoilage, potentially resulting in higher nutritive value of the forage and subsequent increase of animal performance.

The first objective of this study was to screen a set of technical lignins for their antifungal properties against 4 fungi isolated from spoiled alfalfa (Medicago sativa L.) hay (experiment 1). The second objective was to determine the MIC and minimum fungicidal concentration (MFC) of the most promising technical lignins from experiment 1 . The third objective was to evaluate the dose-optimized technical lignins from experiment 2 for their potential preservation properties in ground high-moisture alfalfa hay as measured by DM losses, microbial counts, nutritional composition, ruminal digestibility, and fermentation profile, using an in vitro aerobic incubation assay. We hypothesized that technical lignins can reduce DM losses and preserve the nutritive value of ground high-moisture alfalfa hay in vitro.

\section{MATERIALS AND METHODS}

\section{Fungal Isolates}

Fungi were isolated from moldy alfalfa hay (Medicago sativa, Pioneer 54QR04) harvested from a field in Exeter, Maine. Bales were stored under cover in high-humidity conditions, and moldiness was determined visually. Isolates were extracted as outlined by
Müller et al. (2011) and plated on malt extract agar (MEA; BD Difco, Franklin Lakes, NJ). Identification to the species level was accomplished by a combination of morphological characters (Malloch, 1981) and DNA sequencing. Molecular identification used the internal transcribed spacer regions (ITS1 and ITS2) of the rRNA genes, the $\beta$-tubulin, and the $28 \mathrm{~S}$ large-subunit ribosomal RNA genes.

\section{Molecular Identification}

Fungal isolates were grown for $7 \mathrm{~d}$ at $25^{\circ} \mathrm{C}$ on MEA covered with sterile transparent cellophane (Bio-Rad, Hercules, CA). The mycelia were carefully removed with the aid of a scalpel, transferred to a sterile microcentrifuge tube, and ground to a fine powder under liquid $\mathrm{N}_{2}$ with a pestle (Goodwin and Annis, 1991). The DNA was extracted using an E.Z.N.A. fungal DNA Mini Kit (Omega Bio-tek, Norcross, GA) and quality and quantity were evaluated by absorbance spectroscopy at 260 and $280 \mathrm{~nm}$ with a NanoDrop 2000 (Thermo Fisher Scientific, Waltham, MA).

The amplification of the ITS regions, 28S rRNA, and $\beta$-tubulin genes of these isolates was performed using the following primer pairs: for ITS1 and ITS2 regions, ITS1 primer 5'-TCCGTAGGTGAACCTGCGG3' and ITS4 primer 5'-TCCTCCGCTTATTGATATGC-3' (White et al., 1990); for the 28S rRNA, NL1 5'-GCATATCAATAAGCGGAGGAAAAG-3' and NL4 5'-GGTCCGTGTTTCAAGACGG-3' (O'Donnell, 1993); and for $\beta$-tubulin, Bt2a primer 5'-GGTAACCAAATCGGTGCTGCTTTC-3' and Bt2b primer 5'-ACCCTCAGTGTAGTGACCCTTGGC-3' (Glass and Donaldson, 1995). The PCR amplifications were conducted in $25-\mu \mathrm{L}$ reactions using a C1000 Touch Thermal Cycler (Bio-Rad). The reaction contained 0.2 $\mathrm{m} M$ dNTP (Promega, Madison, WI), $0.2 \mu M$ of each primer (Integrated DNA Technologies, Coralville, IA), 0.75 units of One Taq DNA polymerase (New England BioLabs, Ipswich, MA), $1 \times$ of One Taq Standard Reaction Buffer (New England BioLabs), $10 \mathrm{ng}$ of DNA template adjusted to be in a volume of $5 \mu \mathrm{L}$, and DNase-free water to make up the final volume. For ITS primers, conditions for amplification were $5 \mathrm{~min}$ at $94^{\circ} \mathrm{C}$, then 30 cycles of $60 \mathrm{~s}$ at $95^{\circ} \mathrm{C}, 60 \mathrm{~s}$ at $55^{\circ} \mathrm{C}, 60$ s at $72^{\circ} \mathrm{C}$, and a final step of $10 \mathrm{~min}$ at $72^{\circ} \mathrm{C}$. For NL1 and NL4, amplification was performed with a slightly different protocol with 5 min at $94^{\circ} \mathrm{C}$, then 35 cycles of $60 \mathrm{~s}$ at $95^{\circ} \mathrm{C}, 60 \mathrm{~s}$ at $53^{\circ} \mathrm{C}, 2 \mathrm{~min}$ at $72^{\circ} \mathrm{C}$, followed by a final cycle of $7 \mathrm{~min}$ at $72^{\circ} \mathrm{C}$. Last, reactions with primers Bt2a and Bt2b were carried out with 5 min at $94^{\circ} \mathrm{C}$, followed by 35 cycles of $60 \mathrm{~s}$ at $95^{\circ} \mathrm{C}, 60 \mathrm{~s}$ at $58^{\circ} \mathrm{C}$, $60 \mathrm{~s}$ at $72^{\circ} \mathrm{C}$, and a final cycle of $10 \mathrm{~min}$ at $72^{\circ} \mathrm{C}$. Amplification products were separated by electrophoresis 
Table 1. Chemical composition of technical lignins ${ }^{1}$

\begin{tabular}{|c|c|c|c|c|c|c|c|c|}
\hline Lignin & $\begin{array}{c}\text { Total } \\
\text { soluble } \\
\text { phenolics }\end{array}$ & $\begin{array}{c}\text { ORAC }^{3} \\
\text { (mmol of Trolox } \\
\text { equivalents/g of DM) }\end{array}$ & $\begin{array}{c}\text { DPPH } \\
\text { scavenging } \\
\text { effect }^{4}(\%)\end{array}$ & \multicolumn{5}{|c|}{$\%$ of DM } \\
\hline$\overline{\mathrm{AKL}}$ & 219.1 & 10.53 & -4.8 & 18.05 & 19.1 & 0.02 & 6.86 & 4.80 \\
\hline AIF & 241.9 & 886.6 & 65.2 & 0.037 & 0.62 & 0.02 & 0.082 & 1.49 \\
\hline HEX & 265.8 & 834.9 & 79.9 & 0.027 & 0.45 & $<0.01$ & 0.009 & 1.49 \\
\hline PI & 382.6 & 888 & 69.4 & 0.025 & 0.07 & $<0.01$ & 0.004 & 1.44 \\
\hline Pooled SD & 9.14 & 34.08 & 12.7 & 0.45 & 0.27 & 0.034 & 0.084 & 0.142 \\
\hline
\end{tabular}

${ }^{1} \mathrm{AKL}=$ alkali kraft lignin (Sigma-Aldrich, St. Louis, MO); LBKL = southern pine softwood kraft lignin; delignified at an $\mathrm{H}$ factor of about 1,600 via the kraft process and precipitated using the Lignoboost process with $\mathrm{CO}_{2}$ as the acid (Tomani, 2010); AIF $=$ LBKL acetone insoluble fraction; HEX = LBKL acetone soluble/hexane soluble fraction; PI = LBKL acetone soluble/hexane insoluble fraction; NaL $=$ sodium lignosulfonate (Sappi North America, Skowhegan, ME); MgL = magnesium lignosulfonate lignin (Sappi North America); and AMOL = ammonium lignosulfonate lignin. The LBKL was donated by D. S. Argyropoulos (North Carolina State University, Raleigh) and LBKL fractions were prepared following the protocol outlined by Cui et al. (2014).

${ }^{2}$ Singleton and Rossi (1965).

${ }^{3}$ Hydrophilic and lipophilic oxygen radical absorbance capacity (ORAC). LBKL, AIF, HEX, and PI were tested by lipophilic ORAC, and AKL, $\mathrm{NaL}, \mathrm{MgL}$, and AMOL were tested by hydrophilic ORAC (Dong et al., 2011).

${ }^{4} \mathrm{Wu}$ et al. (2006) and method 2012.04 (AOAC International, 2012). DPPH = 2,2-diphenyl-1-picrylhydrazyl.

${ }^{5} \mathrm{WSC}=$ water-soluble carbohydrates; DuBois et al. (1956).

${ }^{6} \mathrm{FAO}(2008)$.

${ }^{7}$ Beliciu et al. (2012).

in $1.2 \%$ agarose gel (Cambrex Bio Science, Rockland, ME) with $1 \times$ TBE $(0.089 M$ Tris-borate, $0.002 M$ EDTA), stained with GelStar (Lonza, Rockland, ME), and viewed under $280 \mathrm{~nm}$ UV to see band sizes.

The amplified products were purified with a QIAquick PCR purification kit (Qiagen, Hilden, Germany), and sequenced in the University of Maine DNA Sequencing laboratory (Sanger et al., 1977). Sequence data were edited, assembled, and aligned using the CAP3 sequence assembly program (Huang and Madan, 1999) to obtain high-quality consensus sequences. Consensus sequence homologies were compared with those referenced in the National Center for Biotechnology Information database using the BLASTN search with default parameters (Altschul et al., 1990). Aspergillus amoenus, Mucor circinelloides, Penicillium solitum, and Debaryomyces hansenii were each identified by $\geq 99 \%$ identity match to published sequences in GenBank and $\mathrm{E}$-value $=0.0$. Fungal isolates were preserved as spores (molds) and cells (yeast) in a 30\% glycerol solution at $-80^{\circ} \mathrm{C}$ in cryogenic vials (Corning Inc., Corning, NY).

\section{Experiment 1}

Additives. Table 1 summarizes the set of technical lignins evaluated in this study. We also included in our evaluation propionic acid [positive control (PRP); 99.8\%, MP Biomedicals, Solon, $\mathrm{OH}]$ and a control (untreated). Ash (FAO, 2008), water-soluble carbohy- drates (WSC; DuBois et al., 1956), minerals (Beliciu et al., 2012), and total soluble phenolics concentrations, oxygen radical absorbance capacity (Dong et al., 2011), and 2,2-diphenyl-1-picrylhydrazyl antioxidant activity (Wu et al., 2006) of the lignins are listed in Table 1.

Antifungal Assay. The antifungal activity of additives (ADV) against the isolated fungi was determined using the poisoned food technique according to the method outlined by Balouiri et al. (2016). The assay was done in duplicate in each of 4 runs for each fungus. A randomized complete block design (RCBD) with a $10(\mathrm{ADV}) \times 3$ (molds) factorial arrangement of treatments and 4 blocks (runs) was used to analyze ADV effects on molds. A RCBD also was used to test the effect of the $10 \mathrm{ADV}$ on yeast (D. hansenii).

Medium Preparation. Sterile MEA was mixed with each ADV as follows. Solutions of lignin and PRP were prepared in sterile nanopure water $(20$ and $32 \% \mathrm{wt} / \mathrm{vol}$, respectively) in 50-mL polypropylene tubes. Dimethyl sulfoxide (DMSO; Fisher Scientific, Pittsburgh, PA) was added at $8 \%$ (vol/vol) to all treatments because there was a need to increase the solubility of kraft lignins. Solutions were sonicated for $60 \mathrm{~min}$ in an 8510 Series Ultrasonic Cleaning Bath (Emerson, St. Louis, $\mathrm{MO})$ containing water at $40^{\circ} \mathrm{C}$ to ensure microbial inactivation with minimal effect on the lignin chemical structure (Piyasena et al., 2003). Subsequently, enough ADV stock solution was added to sterilized agar $\left(40^{\circ} \mathrm{C}\right)$ under stirring to achieve a final concentration of $40 \mathrm{mg}$ / 
$\mathrm{mL}$ ADV and 1\% DMSO (vol/vol; for all ADV), and the agar concentration recommended by the manufacturer. Previous studies indicated that the antimicrobial activity of technical lignins increased when $\mathrm{pH}$ was modified from 6.0 to 3.5 (Baranowski et al., 1980). Furthermore, our preliminary tests across a $\mathrm{pH}$ gradient showed that lignins were more antifungal at $\mathrm{pH}$ 4. Thus, to properly evaluate antimicrobial effects of ADV, enough $\mathrm{HCl}$ was added to set the initial medium $\mathrm{pH}$ to 4 for all treatments, including the control.

Molds Antifungal Assay. After 14 (A. amoenus and P. solitum) or $3 \mathrm{~d}$ of incubation (M. circinelloides), the border of single fungal colonies was punched aseptically with a sterile cork borer (7 mm diameter), and discs were inoculated on the center of ADV-containing and untreated MEA. Plates were incubated at $25 \pm$ $1^{\circ} \mathrm{C}$ for $7 \mathrm{~d}$. At the end of the incubation, the diameters (long and short dimension) of mold growth in control and treated plates were measured using a digital caliper (Beckman Coulter, Pasadena, CA), and the antifungal effect was estimated with the following formula: antifungal activity $(\%)=[(\mathrm{Dc}-\mathrm{Ds}) / \mathrm{Dc}] \times 100$, where $\mathrm{Dc}$ is the average diameter of growth in control plate and Ds is the average diameter of growth in the plate containing the ADV (Balouiri, et al., 2016).

Yeast Antifungal Assay. The antifungal activity of ADV against $D$. hansenii was determined using the method outlined by Li et al. (2016) with modifications. The ADV-containing and control plates of MEA were inoculated with $100 \mu \mathrm{L}$ of yeast inoculum containing approximately $1 \times 10^{3} \mathrm{cfu} / \mathrm{mL}$, which was spread around the plate. Plates were incubated at $25 \pm 1^{\circ} \mathrm{C}$ for $72 \mathrm{~h}$ before yeast colonies were enumerated. The antifungal effect was estimated with the following formula: antifungal activity $(\%)=[(\mathrm{Cc}-\mathrm{Cs}) / \mathrm{Cc}] \times 100$, where $\mathrm{Cc}$ is the number of cfu on the control plate and $\mathrm{Cs}$ is the number of cfu on the plate containing the ADV.

\section{Experiment 2}

Additives. Following the results from experiment 1, the MIC and MFC were determined for sodium lignosulfonate ( $\mathbf{N a L})$, magnesium lignosulfonate $(\mathbf{M g L})$, and alkali kraft lignin (AKL), which were the most promising technical lignins, and PRP (positive control) for each of the fungal isolates previously evaluated. Macrodilution assays were carried out independently 3 times in duplicate and values are reported as mean concentrations $(\mathrm{mg} / \mathrm{mL} \pm \mathrm{SD})$.

Antifungal Assay for Molds. After 14 (A. amoenus and $P$. solitum) or $3 \mathrm{~d}$ of incubation (M. circinelloides), fungal spores were washed from the surface of MEA by adding sterile $0.05 \%$ (vol/vol) Tween 20 (Fisher Scientific, Pittsburgh, PA), and then the surface was gently rubbed with a sterile glass hockey stick to loosen spores. This solution was pipetted off into a sterile 15$\mathrm{mL}$ tube, heavy particles were allowed to settle for 3 to $5 \mathrm{~min}$, and the upper homogeneous suspension was transferred to another sterile tube. Subsequently, the spore concentration of this suspension was enumerated with a hemocytometer chamber, diluted, and dispensed to obtain a final concentration of $5 \times 10^{4}$ conidia $/ \mathrm{mL}$ in the treatment medium (Rex et al., 2008).

Antifungal Assay for Yeast. Debaryomyces hansenii was grown on MEA for $72 \mathrm{~h}$. The inoculum was prepared by picking 5 yeast colonies of approximately $1 \mathrm{~mm}$ diameter and suspending them in $5 \mathrm{~mL}$ of sterile $0.145 \mathrm{M}$ saline solution $(8.5 \mathrm{~g} / \mathrm{L} \mathrm{NaCl})$ by shaking on a vortex mixer for $15 \mathrm{~s}$ (CLSI, 2002). The suspension was adjusted with a V-1200 spectrophotometer (VWR, Radnor, PA) to an optical density at $600 \mathrm{~nm}$ of 0.2 , diluted, and dispensed to yield a final concentration of $1 \times 10^{4} \mathrm{cfu} / \mathrm{mL}$ in the treatment medium.

Assay. The MIC was defined as the lowest concentration of ADV that prevented visible growth when compared with untreated controls. The macrodilution testing was performed according to CLSI (2002). Lignins and PRP stock solutions were prepared in sterile malt extract broth (BD Difco, Franklin Lakes, NJ) and sonicated as described in experiment 1 , without using DMSO. According to the concentration tested (ranging from 1.5 to $60 \mathrm{mg} / \mathrm{mL}$ ), different proportions of stock ADV and sterile malt extract broth were dispensed into 50-mL Erlenmeyer flasks to produce final volumes of $5 \mathrm{~mL}$ of medium. To achieve a final $\mathrm{pH}$ of 4 or 6 in the medium, $\mathrm{HCl}$ or $\mathrm{NaOH}$ was added, respectively. Flasks were inoculated with each fungal inoculum, covered with a double layer of sterile aluminum foil, and incubated at $25^{\circ} \mathrm{C}$ for $5 \mathrm{~d}$ with shaking $(60 \mathrm{rpm})$. After this period, an aliquot $(100 \mu \mathrm{L})$ was taken from each flask lacking visible growth and inoculated on fresh MEA plates. Plates were incubated at $25^{\circ} \mathrm{C}$ for $48 \mathrm{~h}$ to determine if there were still live cells and therefore to find the MFC, which was defined as the lowest concentration of ADV that decreases $99.8 \%$ of the initial fungal concentration.

\section{Experiment 3}

Substrate, Additives, and Design. An established stand of alfalfa (Medicago sativa, Pioneer 54QR04) located in Exeter, Maine, was fertilized based on soil test results and recommendations for alfalfa production in Maine (Hoskins, 1997). On June 8, 2018, 5 randomly located plots in the alfalfa stand (first cut, bud stage) were mowed to $7.6-\mathrm{cm}$ stubble height with a BCS 725 sickle bar mower (Portland, OR), allowed to wilt in the field for $5 \mathrm{~d}$ to an $80 \%$ DM concentration, and 
then safely stored in a room protected from rain and soil moisture. Afterward, the alfalfa hay collected from each plot was chopped with a chipper shredder (DR, Vergennes, VT), dried at $60^{\circ} \mathrm{C}$ in a convection oven for $48 \mathrm{~h}(94 \% \mathrm{DM})$, and ground to pass through a $3-\mathrm{mm}$ screen of a Wiley mill (Arthur H. Thomas Company, Philadelphia, PA) for later use in the antifungal activity assay.

The effects of 2 dose-optimized ADV (NaL and $\mathrm{MgL}$ ), selected due to their antifungal activity in aforementioned experiments, and PRP (positive control) on the spoilage of ground high-moisture alfalfa hay were evaluated in vitro using a RCBD with a 3 (ADV: NaL, $\mathrm{MgL}$, and PRP $) \times 4($ dose: $0,0.5,1$, and $3 \% \mathrm{wt} / \mathrm{wt}$, fresh basis) factorial arrangement of treatments and 5 blocks (alfalfa stand plots).

Antifungal Activity. The antifungal activity of ADV on ground high-moisture alfalfa hay (30\% moisture concentration) was evaluated using an in vitro aerobic incubation according to the jar method outlined by Lacey and Lord (1977) with modifications to reach target moisture, $\mathrm{pH}$, and inoculation levels as shown in Figure 1. An incubation period of $15 \mathrm{~d}$ was chosen because undesirable heating of hay caused by aerobic spoilage occurs during the first 2 to 5 wk of storage (Collins and Coblentz, 2007).

Sampling Procedure. At d 0 and 15, samples were taken from each replicate for the determination of nutritional value (10 $\mathrm{g}$, fresh basis) and microbial counts (10 g, fresh basis). In the case of d 0, samples were obtained immediately after inoculation.

Nutritional Analysis. From samples taken at d 0 and 15 , subsamples were processed for the determination of DM concentration by drying at $60^{\circ} \mathrm{C}$ until constant weight in a forced-air oven. Dried samples were ground to pass a 2-mm screen using a Foss Cyclotec mill (Foss, Hillerød, Denmark). Ground samples were analyzed for ash (FAO, 2008). Concentrations of NDF (Van Soest et al., 1991) and ADF (AOAC International, 2000) were measured sequentially using an Ankom 200 Fiber Analyzer (Ankom, Macedon, NY). Heat-stable $\alpha$-amylase was used for the NDF assay, but sodium sulfite was not used. Hemicellulose concentration (NDF minus ADF) was calculated. Hay N concentration was determined using the total Kjeldahl digestion procedure. Digested samples were analyzed colorimetrically using the sodium salicylate-nitroprusside method (Baethgen and Alley, 1989). Crude protein was calculated by multiplying $\mathrm{N}$ concentration by 6.25 (Church, 1993). Water extracts were prepared by mixing $10 \mathrm{~g}$ of fresh alfalfa from subsamples with $90 \mathrm{~mL}$ of $0.1 \%$ sterile peptone water in a $400^{\circ} \mathrm{C}$ Stomacher blender for $3 \mathrm{~min}$ (Seward Ltd., Worthing, UK). The solution was filtered through 2 layers of sterilized cheesecloth and the $\mathrm{pH}$ of the fluid was measured with a calibrated $\Phi 34$ Beckman $\mathrm{pH}$ meter (Beckman, Brea, CA) fitted with an Accumet Universal $\mathrm{pH}$ electrode with an integrated temperature sensor (Thermo Fisher Scientific). Afterward, a portion of the extract was acidified to $\mathrm{pH} 2$ with $50 \% \mathrm{H}_{2} \mathrm{SO}_{4}$ and frozen $\left(-30^{\circ} \mathrm{C}\right)$ until further analysis. Thawed samples were centrifuged at $8,000 \times g$ for 20 min at $4^{\circ} \mathrm{C}$ and the supernatants were kept for further analysis. Ammonia-N $\left(\mathrm{NH}_{3}-\mathrm{N}\right)$ concentration was measured from the acidified samples using an adaptation of the procedure outlined by Weatherburn (1967). Water-soluble carbohydrates were measured using the protocol outlined by DuBois et al. (1956) using sucrose as the standard as described by Hall (2003). Carbon dioxide emissions due to hay spoilage ( $\mathrm{g}$ of $\mathrm{CO}_{2} / \mathrm{kg}$ of hay DM) were estimated using the method proposed by Magan and Aldred (2007) considering that for every $1 \%$ loss of DM, $14.7 \mathrm{~g}$ of $\mathrm{CO}_{2} / \mathrm{kg}$ of substrate $\mathrm{DM}$ will be produced.

Microbiological Analysis. An aliquot was taken immediately after filtering with sterilized cheesecloth and used for enumeration of fungal populations. Serial (10-fold) dilutions were done in $0.1 \%$ sterile peptone water and plated on Dichloran Rose Bengal Chloramphenicol medium (BD Difco, Franklin Lakes, NJ). Plates were incubated for 72 or $120 \mathrm{~h}$ at $25^{\circ} \mathrm{C}$ for yeast and molds, respectively.

In Vitro Ruminal Digestibility and Fermentation. After the 15-d incubation period, all treatments residual alfalfa were evaluated with a 24 -h in vitro ruminal digestibility assay (Hall, 2015). The ruminal fluid was representatively collected by aspiration $3 \mathrm{~h}$ after feeding $(1200 \mathrm{~h})$ from 3 lactating, ruminally cannulated Holstein cows consuming a ration consisting of timothy grass silage (Phleum pretense L.; $6 \mathrm{~kg}$ ), corn silage (Zea mays L.; $6.8 \mathrm{~kg})$, and concentrate $(9.5 \mathrm{~kg}$, DM basis). The ruminal fluid collection protocol was approved by the Institutional Animal Care and Use Committee of the University of Maine. Ruminal fluid was filtered through 2 layers of cheesecloth and flushed with $\mathrm{CO}_{2}$, and $26 \mathrm{~mL}$ of medium containing rumen fluid inoculum and Goering and Van Soest (1970) medium were added to each tube and the suspension was incubated for $24 \mathrm{~h}$ at $39^{\circ} \mathrm{C}$. The fermentations were terminated by placing tubes at $5^{\circ} \mathrm{C}$. Tubes were centrifuged at $900 \times g$ for $20 \mathrm{~min}$ at $4^{\circ} \mathrm{C}$ and filtered through pre-weighed F57 Ankom bags (Ankom). Filtrate samples were analyzed for $\mathrm{pH}$ as previously described, acidified to $\mathrm{pH} 2$ with $50 \% \mathrm{H}_{2} \mathrm{SO}_{4}$, and centrifuged at $8,000 \times \mathrm{g}$ for $20 \mathrm{~min}$ at $4^{\circ} \mathrm{C}$. The supernatant was frozen $\left(-30^{\circ} \mathrm{C}\right)$ and subsequently analyzed for concentration of VFA using an Agilent High Performance Liquid Chromatograph 1200 series system fitted with an Agilent Hi-Plex H column (Agilent Technologies, Santa Clara, CA) coupled to an 


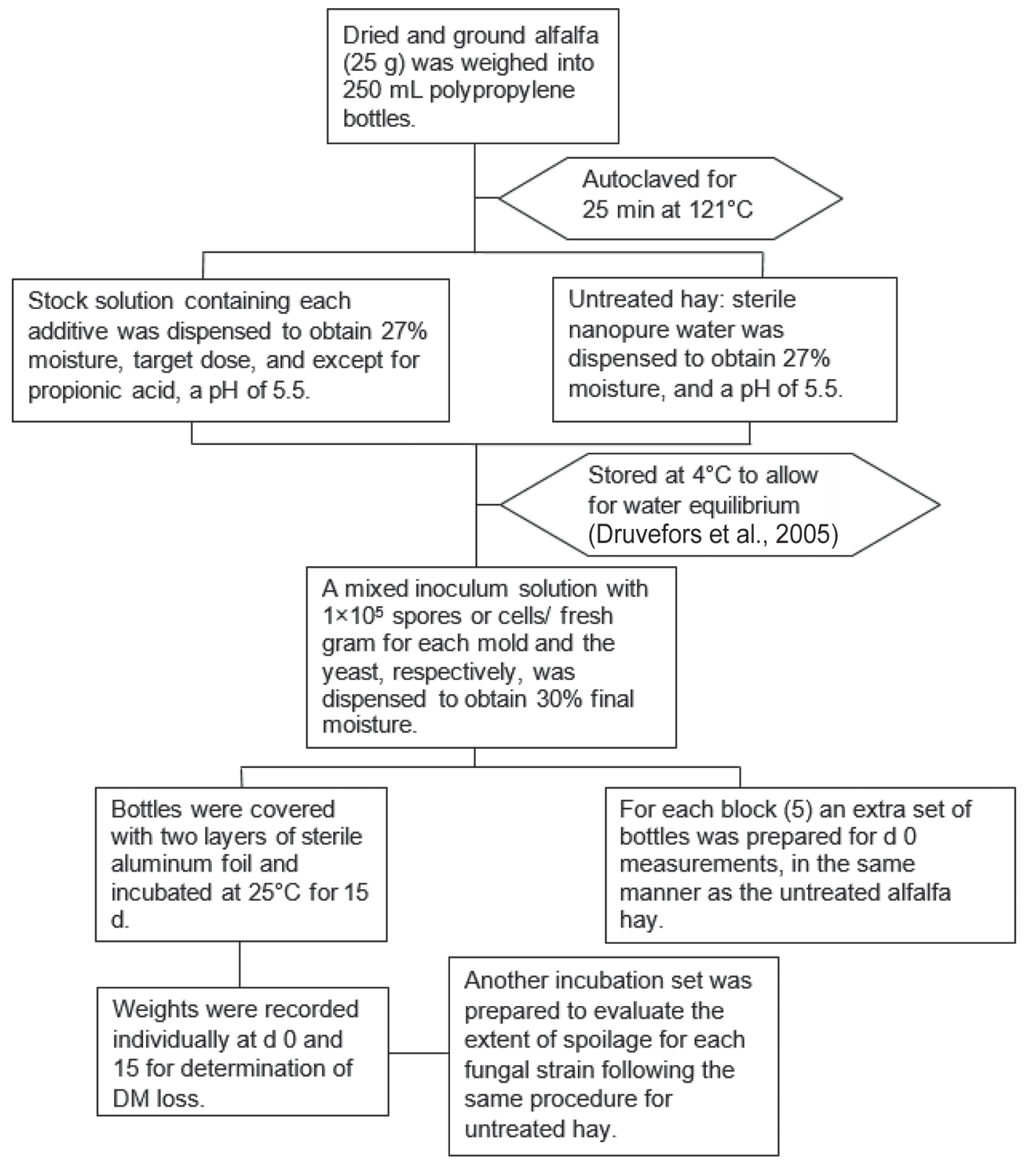

Figure 1. Flowchart for the in vitro aerobic evaluation method of hay spoilage.

Agilent DAD detector set to $210 \mathrm{~nm}$ (Siegfried et al., 1984). Ammonia-N concentration was measured as described previously. Residues contained in Ankom bags were analyzed for NDF as previously described. True dry matter digestibility (DMD) and neutral detergent fiber digestibility (NDFD) were calculated from the residue and original sample weights and their DM and NDF concentrations. Digestible DM recovery (\%) was determined by multiplying DM recovery (\%; final hay weight/initial hay weight on a DM basis $\times 100)$ by true $\operatorname{DMD}(\%)$.

\section{Statistical Analyses}

For experiment 1 , a RCBD with a $10(\mathrm{ADV}) \times 3$ (MOLD) factorial arrangement of additives and 4 blocks (runs) was used to determine the effects of ADV on mold inhibition. The model used to analyze mold inhibition data was

$$
\begin{aligned}
\mathrm{Y}_{\mathrm{ijkl}} & =\mu+\operatorname{MOLD}_{\mathrm{i}}+\mathrm{ADV}_{\mathrm{j}}+\beta_{\mathrm{k}} \\
& +\operatorname{MOLDADV}_{\mathrm{ij}}+\mathrm{E}_{\mathrm{ijk}},
\end{aligned}
$$


where $\mu=$ the general mean, $\mathrm{MOLD}_{\mathrm{i}}=$ the effect of mold $\mathrm{i}, \mathrm{ADV}_{\mathrm{j}}=$ the effect of additive $\mathrm{j}, \beta_{\mathrm{k}}=$ the effect of run $\mathrm{k}$, MOLDADV $\mathrm{ij}_{\mathrm{ij}}=$ the effect of the MOLD i $\times$ ADV $\mathrm{j}$ interaction, and $\mathrm{E}_{\mathrm{ijk}}=$ the experimental error.

A similar model that included only the ADV effect was used to analyze the yeast inhibition data. In the case of experiment 2, MIC and MFC assays were carried out independently 3 times in duplicate and values are reported as mean concentrations $(\mathrm{mg} / \mathrm{mL} \pm \mathrm{SD})$.

For experiment 3 , a RCBD with a $3(\mathrm{ADV}) \times 4$ (dose) factorial arrangement of treatments and 5 blocks (stand plots) was used to determine effects of ADV and dose on spoilage, nutritional composition, and rumen in vitro digestibility and fermentation measures of alfalfa hay. The model used to analyze these data was

$$
\begin{aligned}
\mathrm{Y}_{\mathrm{ijkl}} & =\mu+\operatorname{ADV}_{\mathrm{i}}+\operatorname{DOSE}_{\mathrm{j}}+\beta_{\mathrm{k}} \\
& +\operatorname{ADVDOSE}_{\mathrm{ij}}+\mathrm{E}_{\mathrm{ijk}},
\end{aligned}
$$

where $\mu=$ the general mean, $\mathrm{ADV}_{\mathrm{i}}=$ the effect of additive $\mathrm{i}, \mathrm{DOSE}_{\mathrm{j}}=$ the effect of dose $\mathrm{j}, \beta_{\mathrm{k}}=$ effect of block $\mathrm{k}, \operatorname{ADVDOSE}_{\mathrm{ij}}=$ the effect of the ADV $\mathrm{i} \times$ DOSE $\mathrm{j}$ interaction, and $\mathrm{E}_{\mathrm{ij \textrm {k }}}=$ the experimental error.

The GLM procedure of SAS v. 9.4 (SAS Institute Inc., Cary, NC) was used to analyze the data. When an interaction was present the SLICE option was used. In experiment 1, mean separation was based on the PDIFF procedure of LSMEANS. For experiment 3, polynomial contrasts were used to determine dose effects and Tukey's test was used to compare least squares means within dose and ADV. Both of these mean characterization and separation tests are considered necessary to properly interpret the results because they depict the polynomial trend and the optimal dose, respectively.
Data were tested for normality using the Shapiro-Wilk test. Significance was declared at $P \leq 0.05$.

\section{RESULTS}

\section{Experiment 1}

We found an interaction effect of mold $\times$ ADV on antifungal activity $(P<0.001)$. For $A$. amoenus, $M$. circinelloides, and $P$. solitum we observed that PRP and $\mathrm{NaL}$ had the highest antifungal activity, followed by MgL (Table 2). For NaL, PRP, and LBKL acetone soluble/hexane soluble fraction (HEX), no significant differences were observed across molds. However, for MgL, different antifungal activities were observed across $M$. circinelloides, A. amoenus, and $P$. solitum $(72.9,40.9$, and $28.1 \pm 2.77 \%$, respectively; $P \leq 0.05)$ and a similar trend was observed for AKL (49.7, 12.1, and $-8.0 \pm 2.77 \%$, respectively; $P \leq 0.05$ ). Under the conditions of this test $P$. solitum was the most sensitive mold, followed by $A$. amoenus, and $M$. circinelloides. For D. hansenii, we identified PRP, NaL, and MgL as the most effective treatments (Table 3 ).

\section{Experiment 2}

Table 4 shows the MIC and MFC of technical lignins and PRP against the fungi previously described. Among technical lignins at $\mathrm{pH} 4, \mathrm{NaL}$ had the lowest MIC across molds, with values of 20.0, 25.0, and 33.3 $\mathrm{mg} / \mathrm{mL}$ for A. amoenus, M. circinelloides, and P. solitum, respectively (Table 4). In the case of MgL, MIC values of $33.3,36.7$, and $46.7 \mathrm{mg} / \mathrm{mL}$ were found for $A$. amoenus, M. circinelloides, and P. solitum, respectively. None of the technical lignins tested inhibited the molds

\begin{tabular}{|c|c|c|c|c|c|c|c|c|}
\hline \multirow[b]{2}{*}{$\mathrm{ADV}$} & \multicolumn{3}{|c|}{ Antifungal activity $^{2}$} & \multirow[b]{2}{*}{ Mean } & \multirow[b]{2}{*}{ SEM } & \multicolumn{3}{|c|}{$P$-value } \\
\hline & A. amoenus & M. circinelloides & P. solitum & & & Mold & ADV & Mold $\times$ ADV \\
\hline AKL & $12.1^{\mathrm{C}, \mathrm{b}}$ & $-8.0^{\mathrm{D}, \mathrm{c}}$ & $49.7^{\mathrm{C}, \mathrm{a}}$ & $17.9^{\mathrm{C}}$ & 2.77 & $<0.001$ & $<0.001$ & $<0.001$ \\
\hline LBKL & $4.9^{\mathrm{D}, \mathrm{a}}$ & $-3.0^{\mathrm{D}, \mathrm{b}}$ & $-17.4^{\mathrm{G}, \mathrm{c}}$ & $-5.2^{\mathrm{F}}$ & & & & \\
\hline $\mathrm{AIF}$ & $-2.6^{\mathrm{DE}, \mathrm{b}}$ & $-3.8^{\mathrm{D}, \mathrm{b}}$ & $9.1^{\mathrm{E}, \mathrm{a}}$ & $1.1^{\mathrm{E}}$ & & & & \\
\hline HEX & $-7.1^{\mathrm{E}}$ & $-4.0^{\mathrm{D}}$ & $1.5^{\mathrm{F}}$ & $-3.2^{\mathrm{F}}$ & & & & \\
\hline PI & $4.8^{\mathrm{D}, \mathrm{b}}$ & $8.1^{\mathrm{C}, \mathrm{b}}$ & $23.2^{\mathrm{D}, \mathrm{a}}$ & $12.1^{\mathrm{D}}$ & & & & \\
\hline $\mathrm{NaL}$ & $100^{\mathrm{A}}$ & $100^{\mathrm{A}}$ & $100^{\mathrm{A}}$ & $100^{\mathrm{A}}$ & & & & \\
\hline $\mathrm{MgL}$ & $40.9^{\mathrm{B}, \mathrm{b}}$ & $28.1^{\mathrm{B}, \mathrm{c}}$ & $72.9^{\mathrm{B}, \mathrm{a}}$ & $47.3^{\mathrm{B}}$ & & & & \\
\hline AMOL & $13.2^{\mathrm{C}, \mathrm{b}}$ & $-8.5^{\mathrm{D}, \mathrm{c}}$ & $50.6^{\mathrm{C}, \mathrm{a}}$ & $18.4^{\mathrm{C}}$ & & & & \\
\hline PRP & $100^{A}$ & $100^{\mathrm{A}}$ & $100^{\mathrm{A}}$ & $100^{\mathrm{A}}$ & & & & \\
\hline Mean & $29.7^{\mathrm{b}}$ & $23.2^{\mathrm{c}}$ & $43.3^{\mathrm{a}}$ & & & & & \\
\hline
\end{tabular}

Table 2. Antifungal activity (\%) of additives (ADV) as a function of spoiled forage isolated molds (mold) and $A D V^{1}$

$\overline{\mathrm{A}-\mathrm{G}, \mathrm{a}-\mathrm{c}}$ Means with different uppercase letters within a column and lowercase letters within a row are different, $P \leq 0.05$.

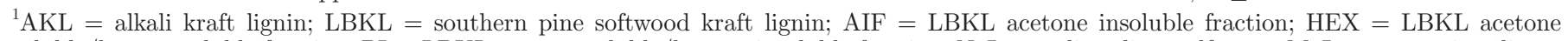

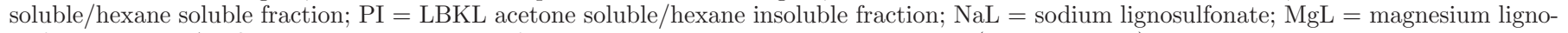
sulfonate lignin; AMOL = ammonium lignosulfonate lignin; and PRP = positive control (propionic acid).

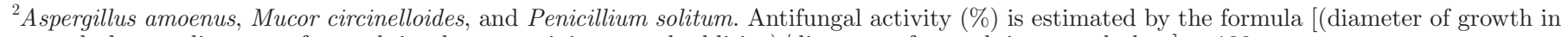
control plate - diameter of growth in plate containing tested additive)/diameter of growth in control plate] $\times 100$. 
at a pH of 6 . The PRP (positive control) was an effective fungistatic agent at both $\mathrm{pH}$ levels tested, but had lower MIC at $\mathrm{pH} 4$, with values as low as 1.25 for A. amoenus and $P$. solitum, and $3.33 \mathrm{mg} / \mathrm{mL}$ for $M$. circinelloides. For the yeast D. hansenii, we found that MgL had a lower MIC compared with NaL (26.7 vs. 40 , respectively) but both had less inhibitory activity relative to PRP $(1.25 \mathrm{mg} / \mathrm{mL})$. No MIC was observed at either $\mathrm{pH}$ for $\mathrm{AKL}$.

In comparing the technical lignins, $\mathrm{NaL}$ at $\mathrm{pH} 4$ had a higher fungicidal activity for $P$. solitum (60.0) and lower for D. hansenii (40.0) compared with $\mathrm{MgL}(>60.0$ and $30.0 \mathrm{mg} / \mathrm{mL}$, respectively). For A. amoenus, NaL and MgL had similar fungicidal activity (40.0). Across all fungi, PRP (positive control) had a lower MFC at both $\mathrm{pH}$ levels compared with the technical lignins tested. However, its fungicidal activity was higher at a $\mathrm{pH}$ of 4 relative to 6 for $A$. amoenus (MFC of 5 vs. 10 , respectively), D. hansenii (5 vs. 15 ), P. solitum (10 vs. 16.7), and M. circinelloides (20 vs. $40 \mathrm{mg} / \mathrm{mL}$ ).

\section{Experiment 3}

DM Losses and Microbial Populations. Effects of treatments on DM loss, $\mathrm{CO}_{2}$ emissions, hay $\mathrm{pH}$, and microbial counts of alfalfa hay at d 15 are shown in Table 5 . We found an interaction effect of ADV $\times$ dose on all of the above variables $(P<0.001)$, except $D$. hansenii counts $(P=0.1)$. For DM loss (Figure 2$)$,

Table 3. Antifungal activity (\%) of additives (ADV) on Debaryomyces hansenii $^{1,2}$

\begin{tabular}{lc}
\hline ADV & Antifungal activity $(\%)$ \\
\hline AKL & $9.8^{\mathrm{bc}}$ \\
LBKL & $8.4^{\mathrm{bc}}$ \\
AIF & $-2.2^{\mathrm{c}}$ \\
HEX & $1.4^{\mathrm{c}}$ \\
PI & $10.6^{\mathrm{b}}$ \\
NaL & $100^{\mathrm{a}}$ \\
MgL & $100^{\mathrm{a}}$ \\
AMOL & $9.9^{\mathrm{bc}}$ \\
PRP & $100^{\mathrm{a}}$ \\
SEM & 3.0 \\
P-value & $<0.001$ \\
\hline
\end{tabular}

${ }^{\mathrm{a}-\mathrm{c}}$ Means with different lowercase letters within a column are different, $P \leq 0.05$.

${ }^{1} \mathrm{AKL}=$ alkali kraft lignin; LBKL $=$ southern pine softwood kraft lignin: $\mathrm{AIF}=\mathrm{LBKL}$ acetone insoluble fraction; HEX $=$ LBKL acetone soluble/hexane soluble fraction; PI = LBKL acetone soluble/hexane insoluble fraction; $\mathrm{NaL}=$ sodium lignosulfonate; $\mathrm{MgL}=$ magnesium lignosulfonate lignin; AMOL = ammonium lignosulfonate lignin; and $\mathrm{PRP}=$ positive control (propionic acid)

${ }^{2}$ Antifungal activity (\%) is estimated by the formula [(colony counts in control plate - colony counts in plate containing tested additive)/ colony counts in control plate] $\times 100$.

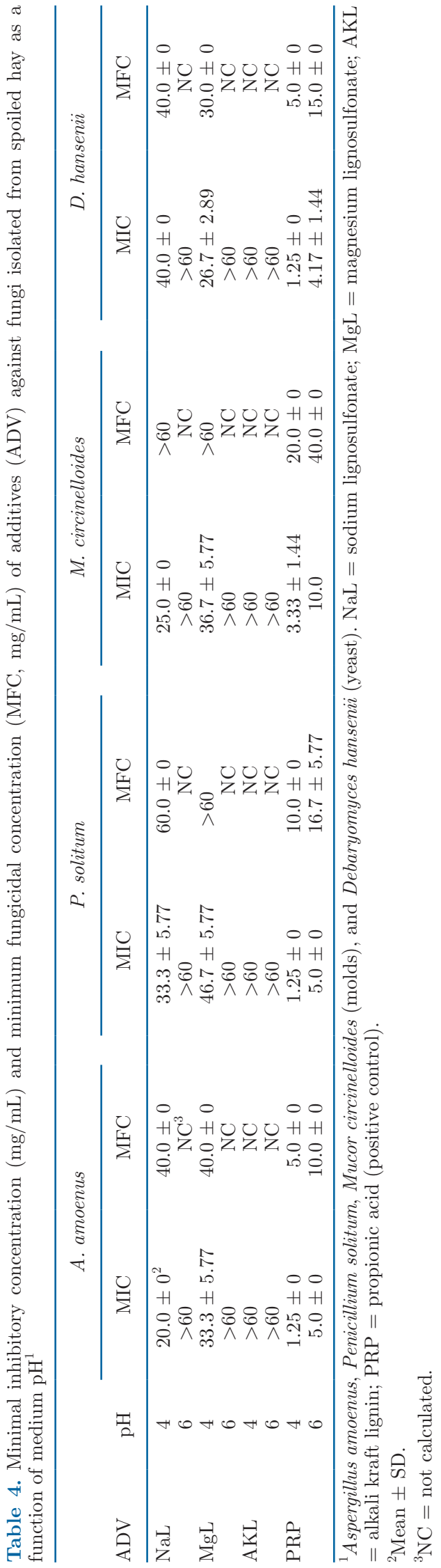


relative to untreated hay (14.9), 1\% was the lowest dose that resulted in the minimum DM losses for $\mathrm{NaL}$ (3.39), $3 \%$ for MgL (0.37), and $0.5 \%$ for PRP (0.47 \pm $0.773 \% ; P<0.001)$. At a dose of $0.5 \%$, PRP reduced $\mathrm{DM}$ losses to a greater extent compared with $\mathrm{NaL}$ and $\mathrm{MgL}$, which were not different. However, at $1 \%$ both $\mathrm{NaL}$ and PRP had similar results, and at 3\% all ADV were similar. A decrease in $\mathrm{CO}_{2}$ emissions relative to untreated hay was observed for $\mathrm{NaL}$ at $1 \%, \mathrm{MgL}$ at $3 \%$, and PRP at $0.5 \%(P<0.001)$ and above (Table 5$)$.

Propionic acid had a higher antifungal effect (1.96) against D. hansenii compared with $\mathrm{NaL}$ and $\mathrm{MgL}$, which were similar (3.54 and $4.67 \pm 0.914 \log \mathrm{cfu} /$ fresh g, respectively; $P<0.001$ ). Across all ADV, a $0.5 \%$ dose decreased $D$. hansenii counts to the greatest extent versus untreated hay $(P<0.001)$. Total mold counts were reduced by $3 \% \mathrm{NaL}$ and $0.5 \% \mathrm{PRP}$, relative to untreated hay $(P<0.001)$. At both $0.5 \%$ and $1 \%$, PRP decreased total mold counts further compared with both $\mathrm{NaL}$ and $\mathrm{MgL}$, which showed no decrease; at $3 \%$ all ADV were similar.

Nutritional Composition. We found an interaction between $\mathrm{ADV} \times$ dose on all nutritive value estimates at d $15(P<0.001)$ except for $\mathrm{CP}, \mathrm{ADF}$, and hemicellulose $(P>0.07$; Table 6$)$. The untreated hay DM (62.4) was lower than the values obtained for at least $1 \% \mathrm{NaL}$ (68.7), 3\% MgL (69.1), and 0.5\% PRP (69.2 $\pm 0.491 \%$; $P<0.001$ ), which were numerically similar to the original value observed at d $0(69.3 \%$, Table 7$)$. At a dose of $0.5 \%$, PRP-treated hay had a higher DM \% than NaL and $\mathrm{MgL}$, which were similar. However, at $1 \%$ no difference was observed between NaL and PRP, and at $3 \%$ all ADV were comparable. For CP concentration, ADV and dose had no effects. However, a decrease in hay $\mathrm{NH}_{3}-\mathrm{N}$ was observed for $\mathrm{NaL}$ and $\mathrm{PRP}$ at $0.5 \%$ (0.071 and 0.061 , respectively) and above, and for $\mathrm{MgL}$ at $3 \%$ (0.062), compared with untreated hay $(0.249 \pm 0.007 \%$ DM; $P<0.001)$. When comparing ADV within doses tested, at 0.5 and $1 \%$ both $\mathrm{NaL}$ and PRP resulted in a lower $\mathrm{NH}_{3}-\mathrm{N}$ compared with $\mathrm{MgL}$, whereas at $3 \%$ PRP decreased $\mathrm{NH}_{3}-\mathrm{N}$ to a greater extent than $\mathrm{MgL}$. At $3 \%, \mathrm{NaL} \mathrm{NH}_{3}-\mathrm{N}$ values were not different from either PRP or MgL. Compared with WSC in untreated hay, the doses preserving WSC to the greatest extent were $3 \%$ for $\mathrm{NaL}$ and $\mathrm{MgL}$ and $0.5 \%$ for PRP $(P<0.001)$. At 0.5 and $1 \%$, PRP preserved WSC to greater extent compared with $\mathrm{NaL}$ and $\mathrm{MgL}$, and at $3 \%$ all ADV were comparable (Figure 3). Therefore, NaL at $3 \%$ and PRP at a dose as low as $0.5 \%$ impeded an increase in NDF concentration relative to untreated hay $(P=0.001)$. At 0.5 and $1 \%$, a lower NDF was observed for PRPtreated hay compared with $\mathrm{NaL}$ and MgL. However, at $3 \%$ PRP resulted in a lower NDF compared with MgL, but NaL was similar to both PRP and MgL.
In Vitro Ruminal Digestibility. We found an interaction effect of ADV $\times$ dose on all ruminal in vitro fermentation measures $(P<0.001$; Table 8$)$, except for ruminal $\mathrm{pH}$ and isovalerate concentration. An increased true DMD was observed for $3 \% \mathrm{NaL}$ (67.5), $1 \% \mathrm{MgL}$ (67.0), and $0.5 \%$ PRP (68.5) versus untreated hay (61.8 $\pm 0.771 \%)$. At a dose of $0.5 \%, \mathrm{MgL}$ and PRP increased DMD to the same level, which was higher than that of $\mathrm{NaL}$; at $1 \%$, PRP resulted in higher DMD than NaL, but MgL was similar to both PRP and NaL; and at $3 \%$ all ADV were comparable. Magnesium lignosulfonate and PRP at a dose as low as 0.5\% (56.4 and 68.0, respectively) and NaL at $1 \%$ (63.3) had increased digestible DM recovery compared with untreated hay $(52.6 \pm$ $0.747 \% ; P<0.001)$. Across ADV, at 0.5 and $1 \%$, PRP improved digestible DM recovery to a greater extent compared with both lignosulfonates, but at $3 \%$ all ADV were similar. Similarly, in the case of NDFD (Figure 4), $\mathrm{MgL}$ and PRP at $0.5 \%$ (30.5 and 30.1, respectively) and NaL at 1\% (30.7) increased NDFD compared with untreated hay $(23.3 \pm 1.09 \% ; P<0.003)$. At $0.5 \%$, MgL increased NDFD to a larger extent compared with $\mathrm{NaL}$, but both were not different from PRP, and all ADV were similar at $1 \%$ and $3 \%$.

Sodium lignosulfonate at $3 \%$ decreased ruminal $\mathrm{NH}_{3^{-}}$ $\mathrm{N}$ concentration to the greatest extent versus untreated hay $(P=0.009)$. In contrast, $\mathrm{NaL}$ at $3 \%$ increased total VFA (TVFA) concentration to the greatest extent relative to untreated hay $(P<0.001)$. However, $\mathrm{MgL}$ decreased TVFA at $0.5 \%(P=0.01)$, whereas other MgL doses were similar to untreated. No dose of PRP was different than untreated. At $0.5,1$, and $3 \%, \mathrm{NaL}$ increased TVFA to a greater extent than PRP or MgL. At $0.5 \%$, VFA for PRP was higher than MgL, and both were comparable at 1 and $3 \%$.

\section{DISCUSSION}

\section{Experiments 1 and 2}

A limited number of studies have evaluated the antimicrobial activity of technical lignins (Kim et al., 2013; Kaur et al., 2017; Jha and Kumar, 2018). Interpretation of these results can be challenging due to variation in the types of technical lignin (García et al., 2017), microorganisms (Dong et al., 2011), and methodologies used (Yang et al., 2018). In most articles, a thorough description of the lignin chemical properties is often lacking, which impedes direct comparisons among studies. In our study, $\mathrm{NaL}$ and $\mathrm{MgL}$ were found to have the strongest inhibitory properties among all lignins tested when evaluated against $A$. amoenus, $M$. circinelloides, $P$. solitum (molds), and D. hansenii (yeast) at a $\mathrm{pH}$ of 4. Jha and Kumar (2018) reported MIC values for 
Reyes et al.: POTENTIAL OF TECHNICAL LIGNINS AS HAY PRESERVATIVES

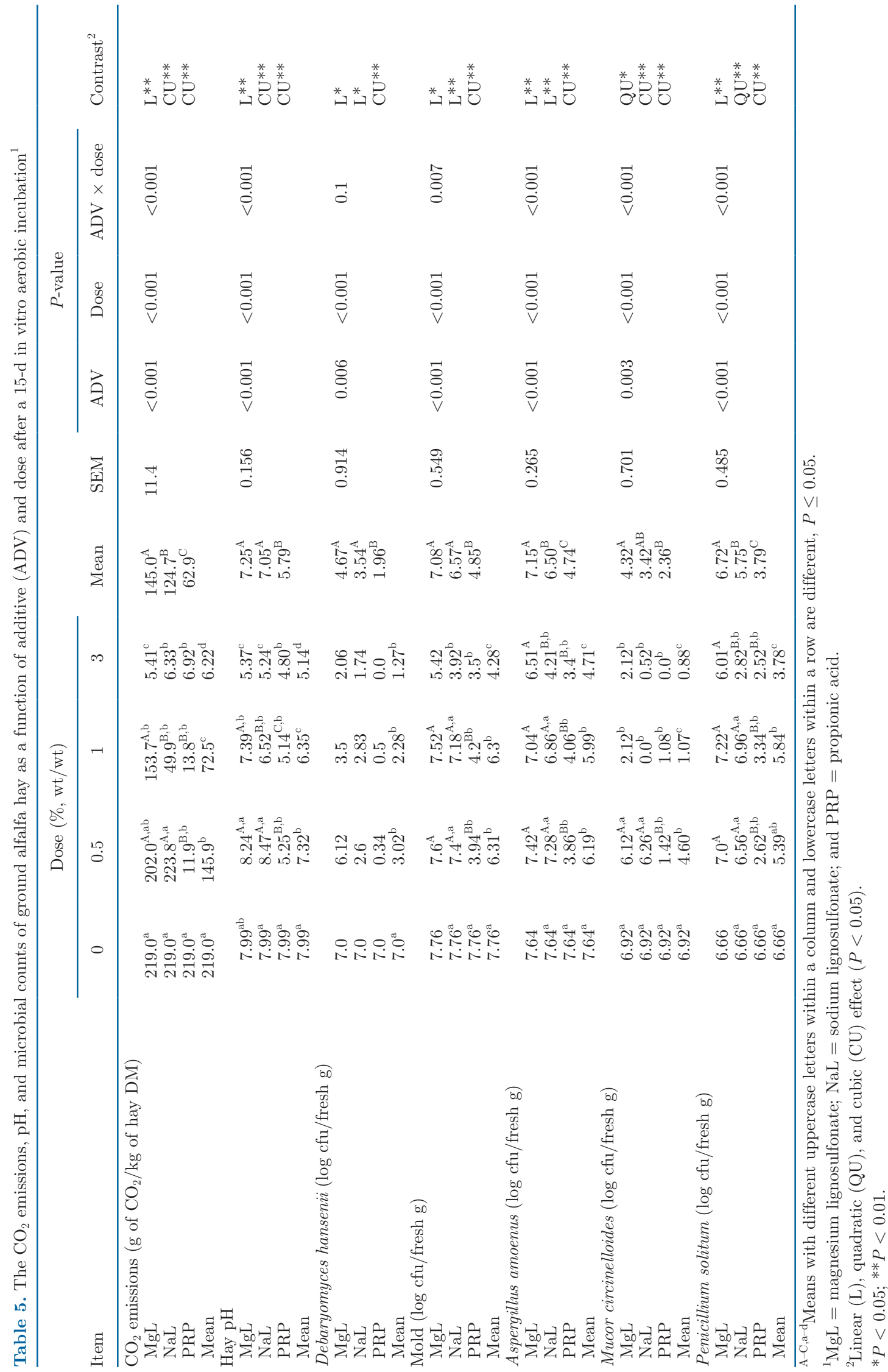


NaL (Sigma-Aldrich Corp., St. Louis, MO) of 50, 62, 62 , and $80 \mu \mathrm{g} / \mathrm{mL}$ for the yeasts Candida dubliniensis, Candida tropicalis, Candida albicans, Candida glabrata, and Candida parasilopsis, respectively. When these values were evaluated using the disc diffusion method, they observed that relative to fluconazole (undisclosed source) the inhibition of diameter growth was $6,10.3$, and $23 \%$ for C. glabrata, C. tropicalis, and C. albicans, respectively. Similarly, Núñez-Flores et al. (2012) reported that an undisclosed dose of $\mathrm{NaL}$ (4\% reducing sugar content; 7,085 Da) extracted from eucalyptus wood (LignoTech Ibérica, S.A. Torrelavega, Spain) showed a $9.9 \%$ growth inhibition for D. hansenii using the disk diffusion method. Our results obtained with $\mathrm{NaL}$ were comparable to those reported by Jha and Kumar (2018) with Candida spp. and Núñez-Flores et al. (2012) with D. hansenii. However, Núñez-Flores et al. (2012) did not observe an inhibitory activity for sodium lignosulfonate against $P$. expansum and Aspergillus niger. This discrepancy with our study may be due to the different Penicillium and Aspergillus species tested, as well as the NaL sources and doses used across studies. Furthermore, these studies did not report medium $\mathrm{pH}$ values. In our study, we observed that medium $\mathrm{pH}$ plays a major role in the extent of the antifungal activity of technical lignins, with a lower $\mathrm{pH}$ (4 vs. 6) resulting in greater inhibition. Baranowski et al. (1980) hypothesized that at a lower $\mathrm{pH}$ the efficacy of ferulic acid increases due to an enhanced membrane permeability in the undissociated state. In that study, ferulic acid at $0.23 \mathrm{mM}$ had antifungal activity against the yeast Saccharomyces cerevisiae at a pH of 3.5 in the medium. However, De Greef and Van Sumere (1966) reported an antimicrobial activity against the same organism for ferulic acid at a dose of $2.5 \mathrm{mM}$ and a medium $\mathrm{pH}$ of 6.0 .

Although the antimicrobial mechanism of lignosulfonates has not yet been elucidated, it is hypothesized that is linked with the strong surfactant properties of lignosulfonates (Núñez-Flores et al., 2012). Surfactants interact with different cellular constituents, especially lipids and proteins, causing adverse effects on the growth and viability of cells by disrupting normal microbial cellular functions (Merianos, 1991; Hugo, 1992). Anionic surfactants synthetized from alkyl ester of phosphoric acid and polyethylene glycol-400 had inhibitory activities of 23 to $26 \mathrm{~mm} / \mathrm{mg}$ and 18 to 25 $\mathrm{mm} / \mathrm{mg}$ for A. niger and C. albicans, respectively, using an inhibition zone diameter test (Negm and Tawfik, 2014). Similarly, Tawfik et al. (2015) reported that synthetized anionic surfactants at doses ranging from 125 to $8,000 \mathrm{ppm}$ decreased the mycelial growth of 8 phytopathogenic fungi from the genera Colletotrichum, Fusarium, Humicola, Pestalotia, Phoma, and Phytophthora, using the poison food technique, by disrupting the native membrane-associated function of integral

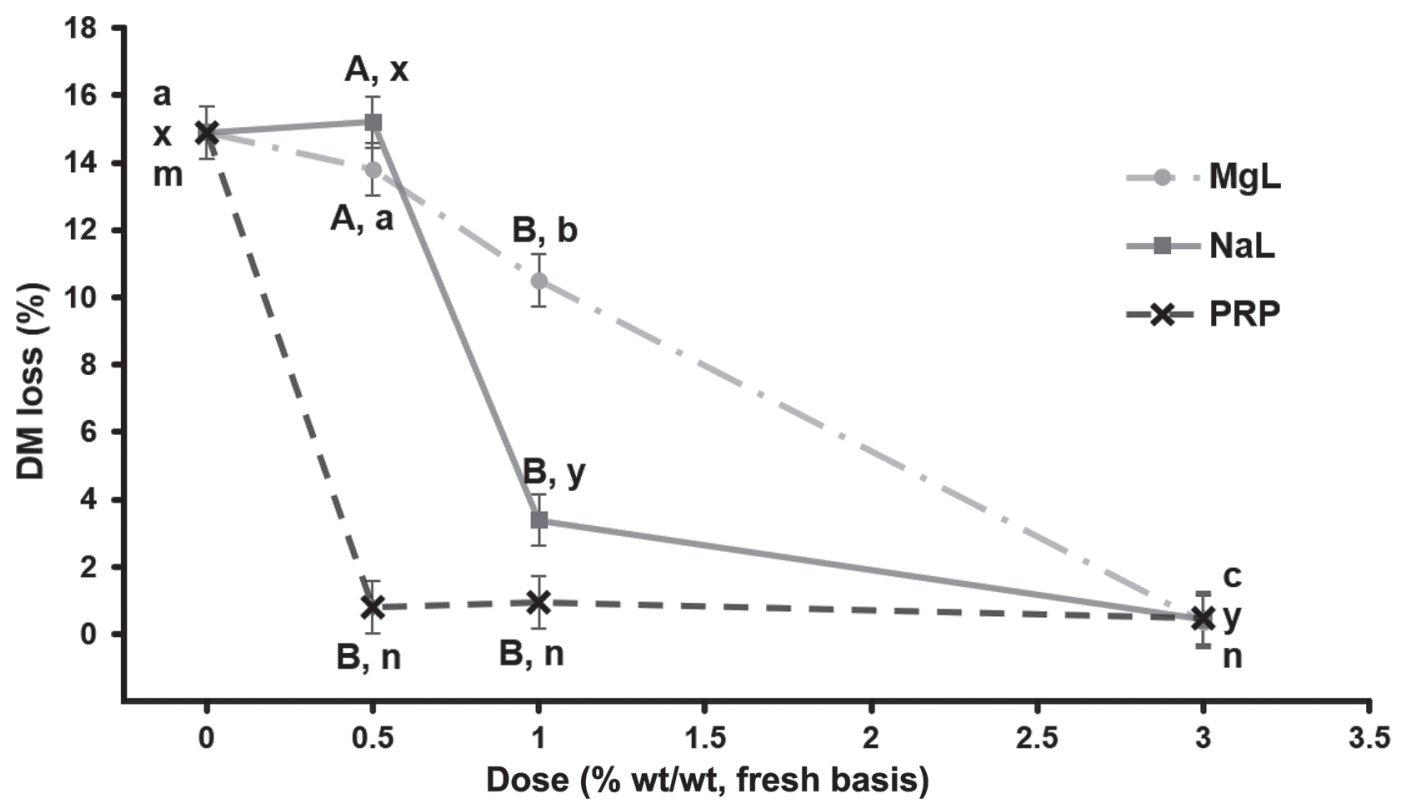

Figure 2. Dry matter loss (\%) of ground alfalfa hay as a function of additive (ADV) and dose after a 15-d in vitro aerobic incubation. MgL $=$ magnesium lignosulfonate; $\mathrm{NaL}=$ sodium lignosulfonate; $\mathrm{PRP}=$ propionic acid. Bars represent means \pm SEM. Uppercase letters depict differences across ADV within dose $(P \leq 0.05)$ and lowercase letters depict differences across dose within ADV (MgL: a, b, c, NaL: $x, y$, and PRP: $\mathrm{m}, \mathrm{n} ; P \leq 0.05)$. 
Reyes et al.: POTENTIAL OF TECHNICAL LIGNINS AS HAY PRESERVATIVES

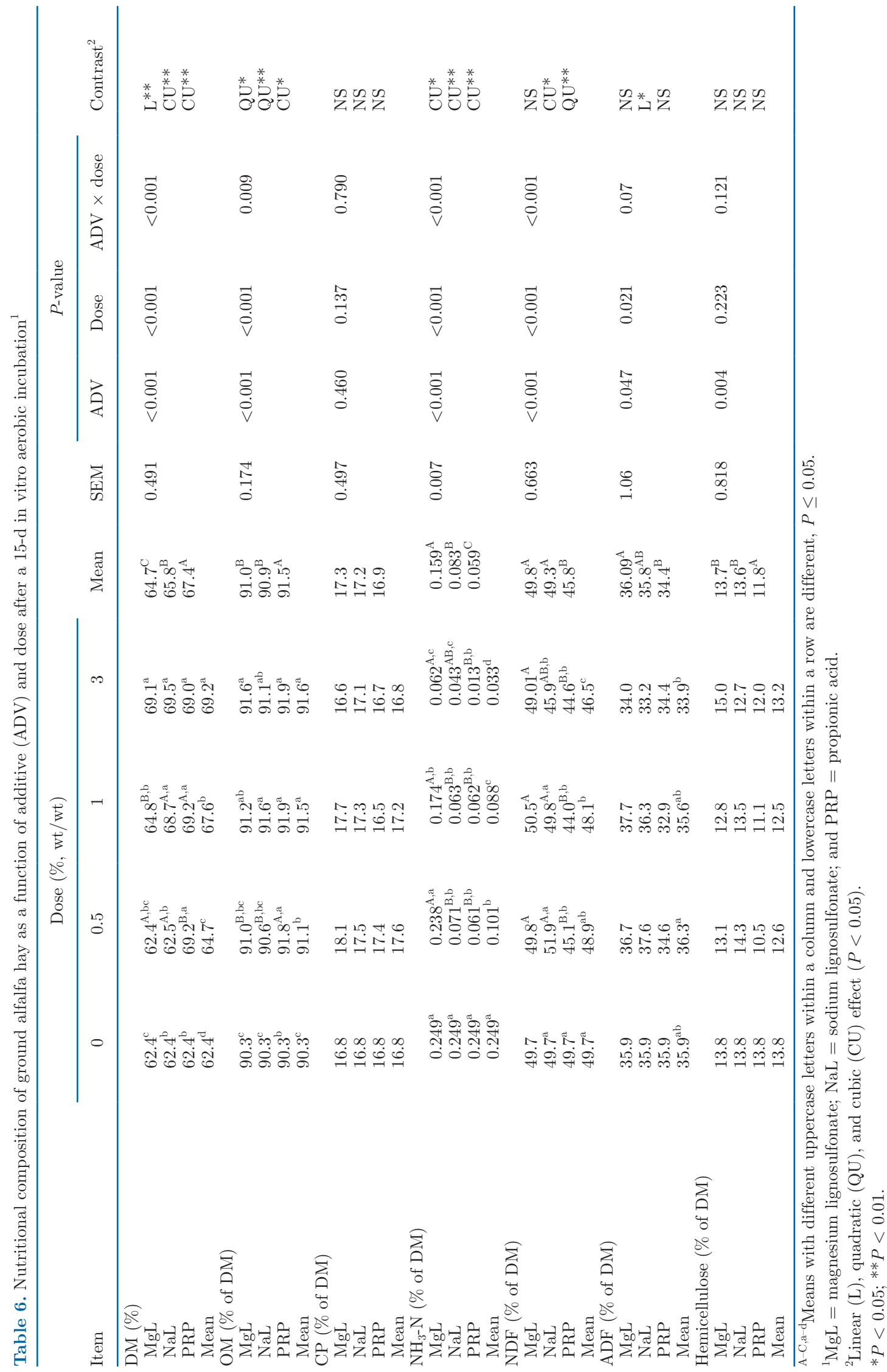


proteins. Lignosulfonates are also anionic surfactants, but their mechanism of action against microbes needs to be investigated.

Fewer studies have been conducted using kraft lignins. Dong et al. (2011) reported a MIC of 0.01 and 0.0025 $\mu \mathrm{g} / \mathrm{mL}$ using AKL (Sigma-Aldrich Corp.) against Candida lipolytica (yeast) and Staphylococcus aureus (bacteria). However, no antibacterial activity was reported against Listeria monocytogenes. The lignin tested in that study had an antioxidant activity of $3,517 \mu \mathrm{mol}$ Trolox equivalents/g and $165.5 \mathrm{mg} / \mathrm{g}$ total soluble phenolics. We believe that the absence of activity against yeast for AKL in our study compared with Dong et al. (2011) is mostly a consequence of the different species evaluated, considering that the lignin source was the same and the methodologies comparable. Although the mode of action of kraft lignins against fungi is unknown, Dizhbite et al. (2004) suggested that for bacteria it is associated with the inhibition of radical processes of bacterial cells. Hence, a correlation between radical scavenging (antioxidant) and antimicrobial activities was suggested (Dizhbite et al., 2004). Similarly, Dong et al. (2011) reported a positive association between antimicrobial and antioxidant activities of lignins. Conversely, Núñez-Flores et al. (2012) did not find such a relationship, which agrees with our findings as the technical lignins with higher radical scavenging activity were less antifungal (Table 1).

In the current study, PRP had fungistatic and fungicidal activity against fungi isolated from spoiled hay at much lower doses compared with $\mathrm{NaL}$ and MgL. The antimicrobial mechanism of action of PRP consists of the disruption of the electrochemical proton gradient when undissociated acid molecules penetrate the cell wall and dissociate internally. This process depletes cellular energy and, therefore, limits cellular growth and metabolic functions (Davidson et al., 2013). In fungi, recent research suggested that PRP induces the generation of reactive oxygen species and mitochondrial dysfunction, leading to oxidative stress and apoptosis (Yun and Lee, 2016). In addition, because the concentration of undissociated acid declines as $\mathrm{pH}$ increases, PRP is more effective at a lower $\mathrm{pH}$ (Lück and Jager, 1997). The lowest doses that were selected for further testing in experiment $3(0.5-1 \%$, wt/wt; fresh basis) corresponded to the actual concentrations typically used in the field for propionic acid $(\sim 0.67-1.34 \%$, wt/ wt; fresh basis) when calculated from the application rate of commercially available propionic acid-based preservatives (1-2\%, wt/wt; fresh basis; Rotz, 2003)

Table 7. Microbial counts, nutritional composition, and 24-h in vitro digestibility and rumen fermentation measurements of untreated ground alfalfa hay at d 0

\begin{tabular}{lc}
\hline Item & Value (mean \pm SD) \\
\hline Microbial count (log cfu/fresh g) & \\
Total mold counts & $5.4 \pm 0.1$ \\
Debaryomyces hansenii counts & $4.8 \pm 0.2$ \\
Aspergillus amoenus counts & $4.9 \pm 0.19$ \\
Mucor circinelloides counts & $4.9 \pm 0.36$ \\
Penicillium solitum counts & $4.7 \pm 0.34$ \\
Nutritional value & \\
DM (\%) & $69.3 \pm 0.6$ \\
Hay pH & $5.52 \pm 0.2$ \\
OM (\% of DM) & $92.4 \pm 0.6$ \\
NDF (\% of DM) & $47.8 \pm 1.2$ \\
ADF (\% of DM) & $34.8 \pm 1.5$ \\
CP (\% of DM) & $16.7 \pm 0.81$ \\
Hay NH ${ }_{3}-\mathrm{N}(\%$ of DM) & $0.065 \pm 0.005$ \\
Water-soluble carbohydrates (\% of DM) & $11.1 \pm 0.59$ \\
In vitro digestibility and rumen fermentation measurement & \\
24-h in vitro DM digestibility (\%) & $66.2 \pm 1.5$ \\
24-h NDF digestibility (\% of DM) & $30.0 \pm 1.2$ \\
Total VFA (mM) & $96.8 \pm 0.9$ \\
Acetate (mM) & $52.7 \pm 0.6$ \\
Propionate (mM) & $22.5 \pm 0.4$ \\
Butyrate (mM) & $12.5 \pm 0.4$ \\
Isobutyrate (mM) & $1.5 \pm 0.2$ \\
Isovalerate (mM) & $3.13 \pm 0.3$ \\
Valerate $(\mathrm{m} M$ ) & $5.45 \pm 0.4$ \\
Acetate-to-propionate ratio & $2.34 \pm 0.03$ \\
Ruminal pH & $6.59 \pm 0.05$ \\
Ruminal NH ${ }_{3}-\mathrm{N}$ (mg/dL) & $54.96 \pm 4.11$ \\
\hline
\end{tabular}




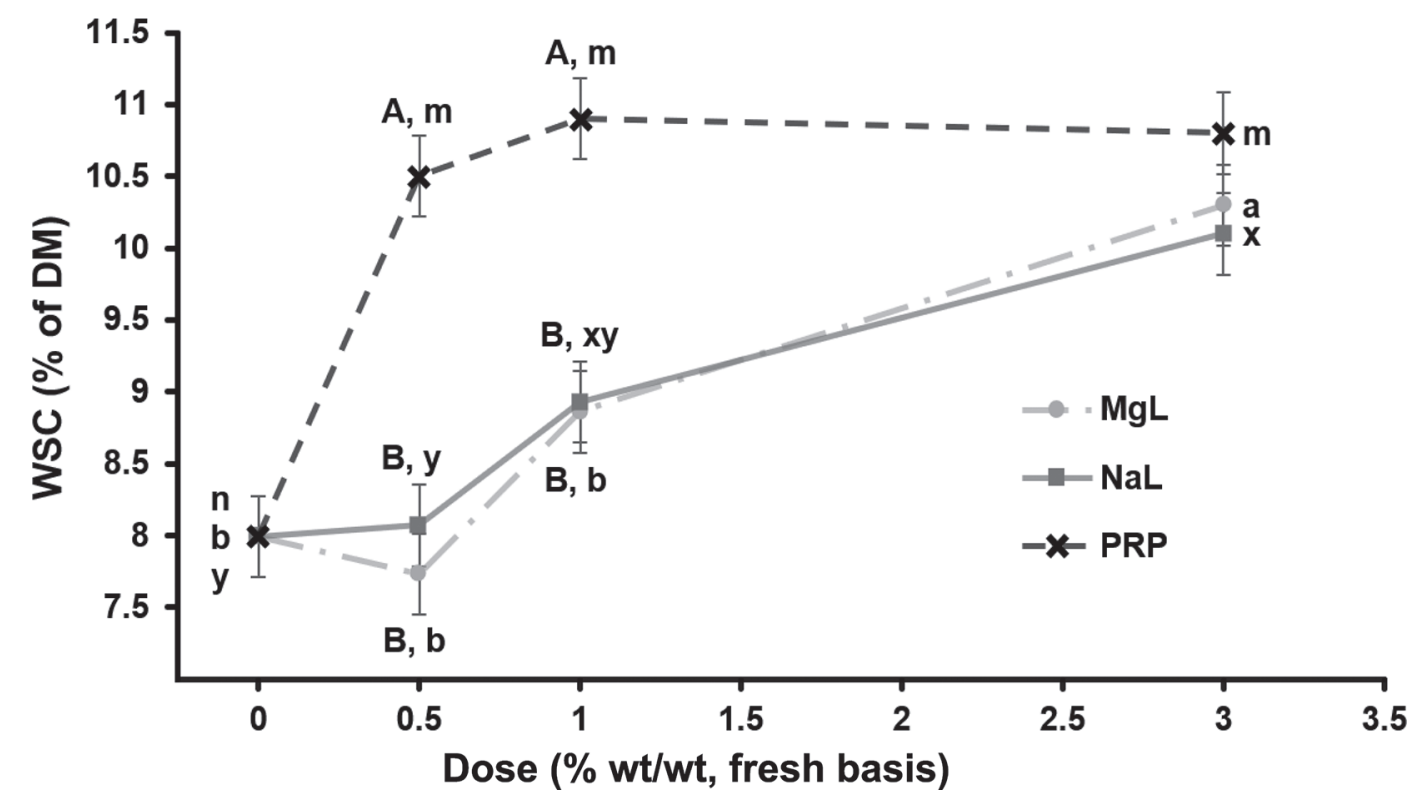

Figure 3. Water-soluble carbohydrates (WSC; \% of DM) of ground alfalfa hay as a function of additive (ADV) and dose after a 15-d in vitro aerobic incubation. $\mathrm{MgL}=$ magnesium lignosulfonate; $\mathrm{NaL}=$ sodium lignosulfonate; $\mathrm{PRP}=$ propionic acid. Bars represent means \pm SEM. Uppercase letters depict differences across ADV within dose $(P \leq 0.05)$ and lowercase letters depict differences across dose within ADV (MgL: a, b, NaL: $x, y$, and PRP: $\mathrm{m}, \mathrm{n} ; P \leq 0.05)$.

and the typical concentration of propionic acid in those commercial products ( $67 \%$, vol/vol; EFSA, 2011).

\section{Experiment 3}

Hay baled above recommended moisture levels (15-20\%) results in spoilage during the storage phase, with DM losses being as high as 30\% (Ball et al., 1998) caused by proliferating fungal populations (Roberts, 1995) that preferably oxidize WSC (Turner et al., 2002) releasing moisture and $\mathrm{CO}_{2}$ (Rees, 1982), and reducing OM concentrations (Coblentz and Hoffman, 2009). Plant proteins are also decomposed in this spoilage process (i.e., proteolysis), releasing $\mathrm{NH}_{3}-\mathrm{N}$ in the process and increasing $\mathrm{pH}$ (Rotz and Muck, 1994). The breakdown and oxidation of rapidly digestible fractions by the spoilage microbial community leaves behind the most recalcitrant and slowly degradable fractions such as NDF and ADF (Coblentz and Bertram, 2012), which affects not only the nutritional composition of spoiled hay but also its digestibility (Montgomery et al., 1986; McBeth et al., 2001; Coblentz and Hoffman, 2010) and the extent and composition of VFA being produced during ruminal fermentation (Mohanty et al., 1969). Furthermore, a significant decrease is present in digestible energy from the recovered DM (Atwal et al., 1984; Russell et al., 1990). This was evident when the nutritional values of untreated hay at d 15 (Table 6) are compared with the ones obtained from untreated hay at $\mathrm{d} 0$ (Table 7 ). The overall nutritional value is severely compromised along with the potential voluntary intake, if we were to consider the NDF percent increase in the spoiled alfalfa hay (Mertens, 1977). The decrease in both nutritional value and voluntary intake can explain the decrease in animal performance that has been reported in spoiled versus well-preserved hays (Deetz et al., 1989; Ziemer et al., 1991).

At d 15, alfalfa hay DM losses were mitigated to the same extent by NaL and PRP at a dose of $1 \%$, with no further benefit observed at a higher dose for both. However, PRP was the only ADV that was able to impede DM losses at a dose $0.5 \%$ due its more potent antifungal activity relative to the other ADV, as reported in experiments 1 and 2. To the best of our knowledge, no studies have measured $\mathrm{CO}_{2}$ emissions during hay storage. A relationship between DM losses and $\mathrm{CO}_{2}$ production has been described for grain crops (Magan and Aldred, 2007). Approximately $14.7 \mathrm{~g}$ of $\mathrm{CO}_{2}$ per $\mathrm{kg}$ of grain is released for every $1 \%$ loss of grain DM during aerobic spoilage. If we were to apply this relationship to hay, a typical 800-kg (DM basis) round bale with a $14.9 \%$ DM loss during storage could release 175 $\mathrm{kg}$ of $\mathrm{CO}_{2}$. In this study, we observed that $\mathrm{NaL}$ and PRP at $1 \%$ decreased theoretical $\mathrm{CO}_{2}$ emissions to the same level. Consequently, if the same $800-\mathrm{kg}$ DM bale would be treated with $1 \% \mathrm{NaL}$, that could represent a potential reduction in $\mathrm{CO}_{2}$ emissions from 175 to 40 $\mathrm{kg}$ of $\mathrm{CO}_{2}$ (77\% decrease). More research needs to be 
Table 8. The 24-h in vitro DM digestibility (DMD), digestible DM recovery, and rumen fermentation measurements of ground alfalfa hay as a function of additive (ADV) and dose after a 15-d in vitro aerobic incubation ${ }^{1}$

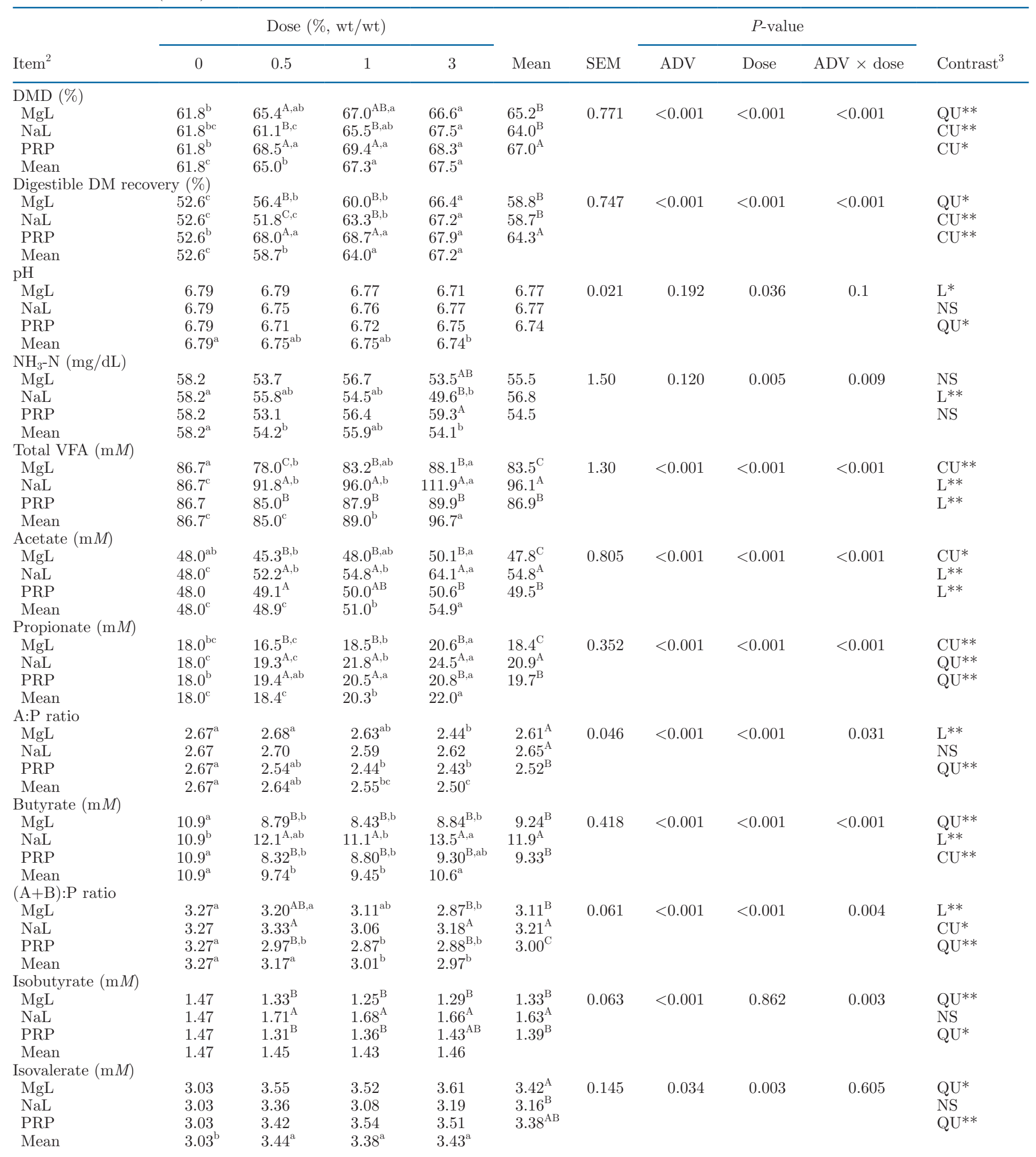


Table 8 (Continued). The 24-h in vitro DM digestibility (DMD), digestible DM recovery, and rumen fermentation measurements of ground alfalfa hay as a function of additive (ADV) and dose after a 15-d in vitro aerobic incubation ${ }^{1}$

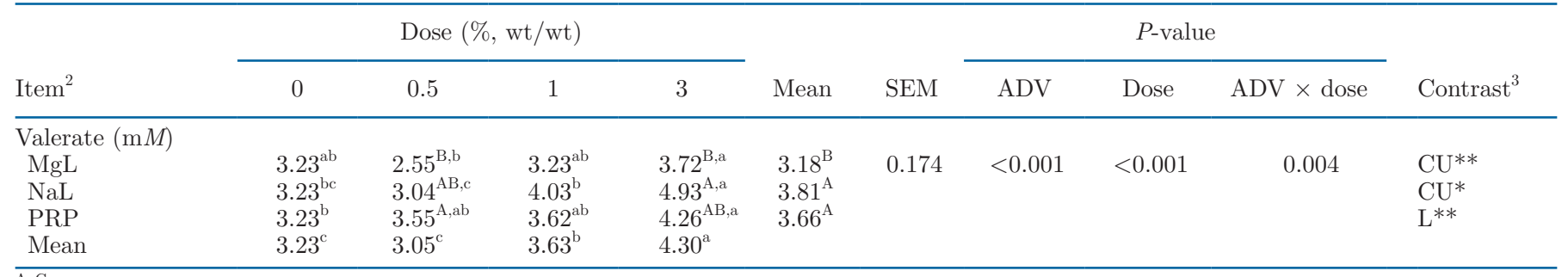

$\overline{\mathrm{A}-\mathrm{C}, \mathrm{a}-\mathrm{C}}$ Means with different uppercase letters within a column and lowercase letters within a row are different, $P \leq 0.05$.

${ }^{1} \mathrm{MgL}=$ magnesium lignosulfonate; $\mathrm{NaL}=$ sodium lignosulfonate; and $\mathrm{PRP}=$ propionic acid.

${ }^{2} \mathrm{~A}=$ acetic acid; $\mathrm{P}=$ propionic acid; $\mathrm{B}=$ butyric acid.

${ }^{3}$ Linear $(\mathrm{L})$, quadratic $(\mathrm{QU})$, and cubic $(\mathrm{CU})$ effect $(P<0.05)$.

${ }^{*} P<0.05 ;{ }^{* *} P<0.01$.

conducted to assess the effects of hay spoilage on greenhouse gases emissions.

Mold and yeast counts were observed to decrease to different extents as doses of different ADV were increased. It is interesting to note that at a dose of $1 \%$, $\mathrm{NaL}$ decreased the yeast but not the total mold counts in spite of a reduction in DM loss. We hypothesize that this apparent discrepancy between DM loss and total mold counts is explained by the differences in metabolic activity between fungal communities exposed (or not) to antifungal compounds. For instance, Vale-Silva et al. (2012) observed that essential oils from oregano de- creased metabolic activity (viability) of fungi without affecting their hyphal growth.

A positive relationship between spoilage extent and fiber concentration has been reported in hay (Coblentz and Hoffman, 2009; Coblentz et al., 2013). This is a consequence of the preferential oxidation of rapidly degradable fractions, such as WSC (Coblentz et al., 1996), which leaves recalcitrant fiber behind, causing a relative increase in fiber concentration (Coblentz and Hoffman, 2009). In our study, NaL and MgL at a dose of $3 \%$ prevented the increase of NDF and the decrease of OM observed in untreated hay, and preserved WSC

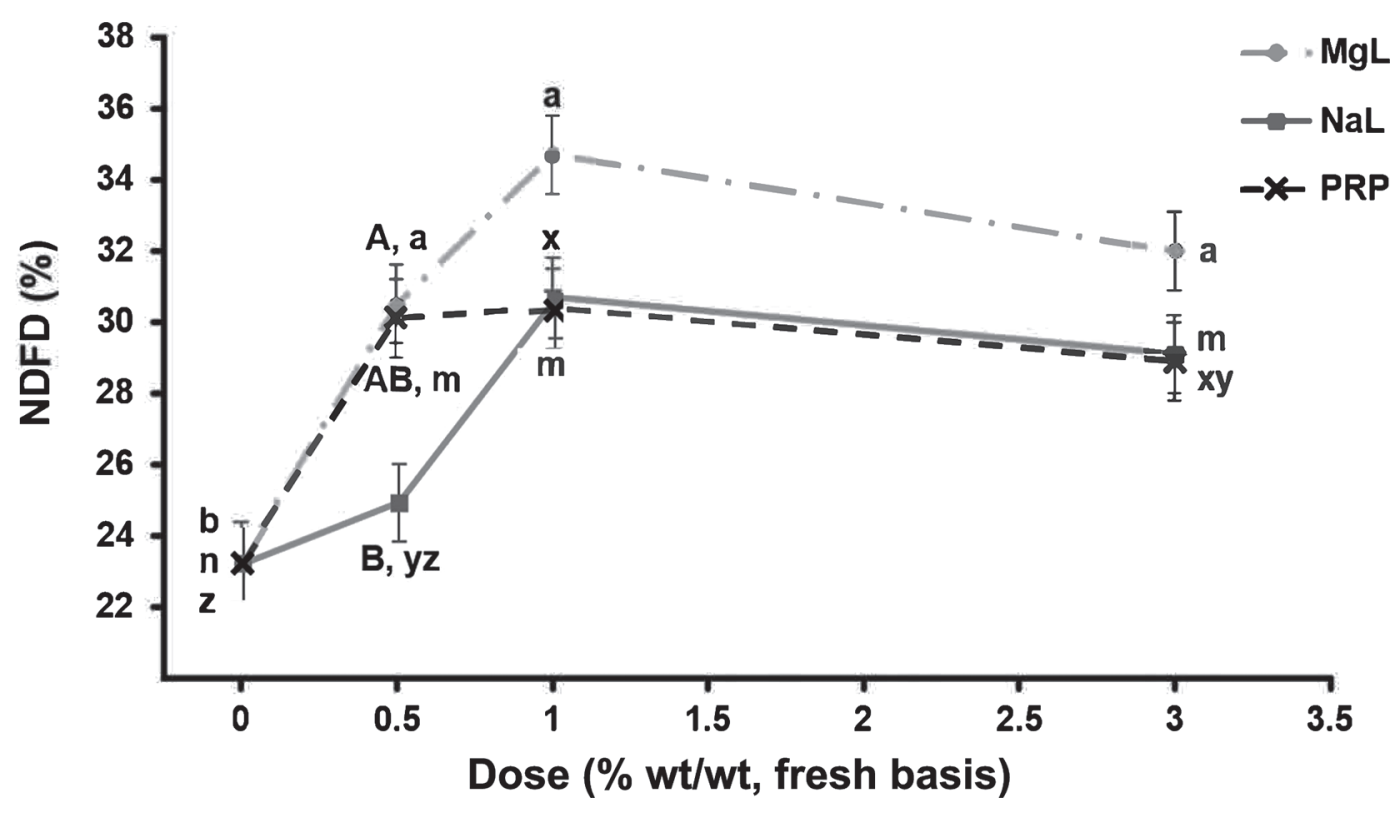

Figure 4. The 24-h in vitro NDF digestibility (NDFD; \%) of ground alfalfa hay as a function of additive (ADV) and dose after a 15-d in vitro aerobic incubation. $\mathrm{MgL}=$ magnesium lignosulfonate; $\mathrm{NaL}=$ sodium lignosulfonate; $\mathrm{PRP}=$ propionic acid. Bars represent means $\pm \mathrm{SEM}$. Uppercase letters depict differences across ADV within dose $(P \leq 0.05)$ and lowercase letters depict differences across dose within ADV (MgL: a, b, NaL: x, y, z, and PRP: m, n; $P \leq 0.05)$. 
to the same extent as PRP at $0.5 \%$. These effects were attributed to the antifungal properties of lignosulfonates (Jha and Kumar, 2018) and PRP (Lacey et al., 1978). Numerous studies have reported PRP as a successful ADV preserving WSC (Knapp et al., 1976; Davies and Warboys, 1982), OM (Coblentz and Hoffman, 2009), and NDF concentrations (Coblentz et al., 2000; Coblentz et al., 2013) found at the time of hay baling.

Sodium lignosulfonate and PRP at $0.5 \%$ showed a protective effect against hay proteolysis, which was observed as a reduction in $\mathrm{NH}_{3}-\mathrm{N}$ relative to the spoiled hay. These results confirm that preservatives can prevent the degradation of plant proteins and preserve their biological value (Rotz and Muck, 1994). Unfortunately, $\mathrm{CP}$ is a measurement with a limited ability to describe proteolysis because it only measures $\mathrm{N}$ concentration. Coblentz et al. (2013) reported minimal changes in CP concentration during the first $60 \mathrm{~d}$ of hay storage. However, after 6 mo, losses of $0.25 \%$ DM of CP per month were observed due to ammonia volatilization (Rotz and Muck, 1994). The incubations of hay with fungi in the current study only lasted for $15 \mathrm{~d}$. Other important protein quality changes result from the formation of insoluble $\mathrm{N}$ components thanks to the Maillard reaction, measured as ADIN (Guerrero and Shenvood, 1997). These compounds are essentially indigestible in ruminants (Schroeder et al., 1996). However, in our study the amount of hay biomass in the incubation $(25$ g, DM basis), which was kept at $25^{\circ} \mathrm{C}$, was not enough to accumulate heat as observed in hay bales (McDonald et al., 1991). These conditions limit the formation of ADIN as a temperature $>50^{\circ} \mathrm{C}$ is required for the Maillard reaction to occur (Guerrero and Shenvood, 1997).

Sodium lignosulfonate at $3 \%$ prevented the increase in $\mathrm{pH}$ observed in the untreated alfalfa hay at d 15, which was caused by spoilage. Chancharoonpong et al. (2012) observed that Aspergillus oryzae increased the $\mathrm{pH}$ of a soybean incubation due to the production of metabolites that included undescribed extracellular proteins. Furthermore, we hypothesize that the increasing $\mathrm{NH}_{3}$ $\mathrm{N}$ concentration due to spoilage contributed to the $\mathrm{pH}$ increase in untreated hay at d 15. Despite not having an effect on the preservation of most nutrient constituents compared with PRP and NaL, MgL applied at 1 and $3 \%$ increased DMD relative to untreated hay at d 15 to the same extent as PRP at the same doses and $\mathrm{NaL}$ at $3 \%$. In the case of PRP and NaL it is evident that the increment in DMD was partially the result of halting the increase in NDF observed with greater spoilage, as their DMD results were similar to untreated hay at $\mathrm{d} 0$. However, MgL did not prevent the increase in NDF due to spoilage and yet it seemed to have stimulated rumen fibrolytic bacteria activity as observed by an increased NDFD at all doses. We hypothesize that the surfactant properties of MgL explain this stimulatory effect on NDFD. Surfactants have been previously reported to improve the adsorption of microbial enzymes onto feed particles, which results in an increase in the rate of digestion of cellulose (Kamande et al., 2000). It also is unlikely that a $\mathrm{Mg}$ deficiency may explain the increase in in vitro digestibility because the Van Soest medium is supplemented with this micromineral (Goering and Van Soest, 1970). The reasons why NaL did not have the same effects, even though it is also a surfactant, remain unclear.

Several studies evaluating the positive effects of lignosulfonates on rumen undegradable protein have reported increases in NDFD of ruminant diets. Stanford et al. (1995) reported that a barley-based diet supplemented with soybean and canola meal treated with calcium lignosulfonate increased in vivo NDFD relative to control in lambs. Similarly, Hussein et al. (1991) found that in grass hay-based diets supplemented with barley treated with calcium lignosulfonate, in vitro NDFD increased relative to control. Furthermore, Wang et al. (2009) reported that diets containing Alcell lignin increased gas production relative to control diets during a $24-\mathrm{h}$ in vitro ruminal fermentation. Conversely, Windschitl and Stern (1988) found a decrease in ruminal in situ ADFD but no effect on NDFD with a corn silage-based diet supplemented with soybean meal treated with calcium lignosulfonate in dairy cattle. Overall, for PRP and $\mathrm{NaL}$, the increase in DMD may be explained by the decrease in NDF concentration and increase in NDFD (Mertens, 2003). However, stimulatory effects of MgL on DMD and NDFD remain unclear due to its null effect on NDF concentration relative to untreated hay at d 15. It is important to note that a $1 \%$ unit increase in in vitro NDFD is associated with a $0.25 \mathrm{~kg} / \mathrm{d}$ increase in $4 \% \mathrm{FCM}$ and a $0.17 \mathrm{~kg} / \mathrm{d}$ increase in DMI (Oba and Allen, 1999). Therefore, feeding hay treated with $1 \%$ MgL could potentially increase milk production by 2.9 and DMI by $1.9 \mathrm{~kg} / \mathrm{d}$, respectively, relative to spoiled alfalfa hay. Further research is needed to understand the effects of lignosulfonates on in vitro ruminal NDFD.

In our study, the increased DMD observed with MgL and PRP relative to untreated hay at d 15 did not result in a TVFA increase. We hypothesize that for these treatments more $\mathrm{OM}$ was used for microbial growth or gas production (Owens and Basalan, 2016). Conversely, NaL had greater TFVA at all doses with the highest concentration observed at a dose of $3 \%$ relative to untreated at d 15 (111.9 vs. $86.7 \mathrm{~m} M$, respectively). Volatile fatty acids contribute $70 \%$ of the caloric requirements in ruminants (Bergman, 1990); therefore, an increase in TVFA could potentially provide lactating cows with a higher energy supply for maintenance, gain, and lactation requirements. Furthermore, NaL 
increased acetate concentration at all doses relative to untreated at $\mathrm{d} 15$. This increased acetate availability may result in additional building blocks for de novo fat synthesis in the mammary gland (Mohammed et al., 2011). Similarly, NaL at 1 and 3\% increased propionate relative to untreated at $\mathrm{d} 15$. Propionate is an important VFA used for glucose synthesis, which is crucial for dairy cattle, especially at early lactation (Drackley, 1999). Butyrate is known to have a stimulatory effect on cell proliferation and ruminal epithelial growth (Górka et al., 2009). Sodium lignosulfonate at $3 \%$ increased butyrate concentration, which could have enhanced VFA absorption. Conversely, MgL (0.5-3\%) and PRP (0.5 and 1\%) had lower butyrate concentrations than those of NaL.

High-producing dairy cattle need to supplement microbial protein with significant amounts of high-quality dietary protein that can escape rumen fermentation (rumen undegradable protein) to meet their AA requirements (Harstad and Prestløkken, 2000). Lignosulfonates have shown a capacity to increase the ruminally undegradable protein fraction (Wright et al., 2005; Borucki Castro et al., 2007; Wang et al., 2009) because they seem to bind and precipitate proteins, as observed in other applications (Cerbulis, 1978; Becker and Lebo, 2002). Therefore, a decrease in ruminal $\mathrm{NH}_{3}-\mathrm{N}$ seems to indicate that NaL at a dose of $3 \%$ reduced ruminal proteolysis and could increase rumen undegradable protein in vivo. Further research is needed to confirm these effects.

Overall, $\mathrm{NaL}$ was the most promising technical lignin tested in preventing spoilage in ground high-moisture alfalfa hay in vitro. We observed that the antifungal properties of lignosulfonates were underestimated when evaluated using an artificial medium versus a ground hay substrate ( $\sim 5$ fold difference). This was most likely due to the limited availability of nutrients and moisture in the ground hay. However, before its implementation in the field, NaL antifungal activity needs to be increased further to match PRP effects. Because the cost of lignosulfonates is around $\$ 600 / \mathrm{Mg}$ and PRPbased products are $\$ 5,000 / \mathrm{Mg}$, the economic margin is enough to cover the costs for the removal of impurities in lignosulfonate products and the isolation of the active antimicrobial fraction, which will allow for a much lower application rate (the cost estimates provided here should be used with caution as they were obtained from industry representatives). Few studies have separated lignosulfonates into fractions with unique physicochemical properties (Ringena et al., 2005; Duval et al., 2015). Unfortunately, none of these studies have evaluated the antimicrobial activity of these fractions. For instance, the $\mathrm{NaL}$ evaluated in our study had high ash and sugar impurities that if removed could significantly increase the antifungal effect. García et al. (2017) reported that the presence of impurities, such as minerals and hemicelluloses in different lignin fractions from apple tree pruning waste, increased the growth of $A$. niger and $S$. cerevisiae. Further studies should be conducted to compare the antifungal activities across a wide range of sodium and magnesium lignosulfonates from different sources.

\section{CONCLUSIONS}

Sodium lignosulfonate was found to be the most antifungal technical lignin due its promising fungistatic activity against $A$. amoenus, $M$. circinelloides, P. solitum (molds), and D. hansenii (yeast) strains isolated from spoiled alfalfa hay. When evaluated in vitro using ground high-moisture hay as substrate, NaL had superior preservation properties measured as decreased DM losses, $\mathrm{NDF}$, fungal counts, and increased WSC, OM, DMD, and NDFD. Furthermore, its antiproteolytic properties were confirmed with a decrease in hay and ruminal in vitro $\mathrm{NH}_{3}-\mathrm{N}$. Also, in vitro ruminal VFA concentration was greatly increased by $\mathrm{NaL}$ relative to all the other ADV tested. However, before its field implementation, NaL preservation effects need to be increased 3-fold to match all the nutritional benefits obtained with PRP hay treatment. Considering the high level of ash and WSC impurities that lignosulfonates have and their low cost, it should be cost effective and feasible to isolate the antimicrobial fraction and increase the antifungal activity several fold. It is interesting to note that even though MgL did not preserve hay nutritional composition as extensively as NaL, it improved DMD and NDFD despite the increase in NDF concentration due to unrestricted spoilage. Previous research points out lignosulfonate stimulatory effects on NDFD due to its surfactant properties, but more research needs to be conducted to understand the mechanisms behind its stimulatory effects on ruminal digestibility.

\section{ACKNOWLEDGMENTS}

We acknowledge the contributions of D. S. Argyropoulos (North Carolina State University, Raleigh), R. Kersbergen (University of Maine Extension, Orono), D. Gomez, H. M. Dubuc, and D. N. DePippo (University of Maine, Orono), the Fogler family (Stonyvale Farm, ME), and the staff from the J. Franklin Witter Teaching and Research Center and Rogers Farm (University of Maine, Orono). This project was supported by the USDA National Institute of Food and Agriculture, Hatch Project number ME0-21717 and AFRI grant 2019-67016-29447 (Animal Nutrition, Growth and Lactation program) through the Maine Agricultural \& For- 
est Experiment Station. Maine Agricultural and Forest Experiment Publication Number 3747. The authors have not stated any conflicts of interest.

\section{REFERENCES}

Altschul, S. F., W. Gish, W. Miller, E. W. Myers, and D. J. Lipman. 1990. Basic local alignment search tool. J. Mol. Biol. 215:403-410. https://doi.org/10.1016/S0022-2836(05)80360-2.

AOAC International. 2000. Official Methods of Analysis of AOAC International. 17th ed. AOAC Int., Arlington, VA.

AOAC International. 2012. Official Methods of Analysis of AOAC International. 19th ed. AOAC Int., Arlington, VA.

Atwal, A. S., F. Sauer, and J. D. Erfle. 1984. Effects of storage conditions for large round bales on recovery and quality of alfalfa hay. Can. J. Anim. Sci. 64:487-490. https://doi.org/10.4141/cjas84 -055 .

Baethgen, W., and M. Alley. 1989. A manual colorimetric procedure for measuring ammonium nitrogen in soil and plant Kjeldahl digests. J. Comm. Soil Sci. Plant Anal. 20:961-969. https://doi.org/ 10.1080/00103628909368129.

Ball, D., D. Bade, G. Lacefield, N. Martin, and B. Pinkerton. 1998. Minimizing losses in hay storage and feeding. Page 16 in National Forage Information Circular. Vol. 98.

Balouiri, M., M. Sadiki, and S. K. Ibnsouda. 2016. Methods for in vitro evaluating antimicrobial activity: A review. J. Pharm. Anal. 6:71-79. https://doi.org/10.1016/j.jpha.2015.11.005.

Baranowski, J., P. Davidson, C. Nagel, and A. Branen. 1980. Inhibition of Saccharomyces cerevisiae by naturally occurring hydroxycinnamates. J. Food Sci. 45:592-594. https://doi.org/10.1111/j .1365-2621.1980.tb04107.x.

Becker, N., and S. Lebo Jr. 2002. Recovery of proteins by precipitation using lignosulfonates. Google Patents. WO1998030580A1.

Beliciu, C. M., A. Sauer, and C. I. Moraru. 2012. The effect of commercial sterilization regimens on micellar casein concentrates. J. Dairy Sci. 95:5510-5526. https://doi.org/10.3168/jds.2011-4875.

Bergman, E. N. 1990. Energy contributions of volatile fatty acids from the gastrointestinal tract in various species. Physiol. Rev. 70:567590. https://doi.org/10.1152/physrev.1990.70.2.567.

Borucki Castro, S. I., L. E. Phillip, H. Lapierre, P. W. Jardon, and R. Berthiaume. 2007. Ruminal degradability and intestinal digestibility of protein and amino acids in treated soybean meal products. J. Dairy Sci. 90:810-822. https://doi.org/10.3168/jds.S0022 -0302(07)71565-5.

Cerbulis, J. 1978. Precipitation of proteins from whey with bentonite and lignosulfonate. J. Agric. Food Chem. 26:806-809. https://doi .org/10.1021/jf60218a032.

Chancharoonpong, C., P.-C. Hsieh, and S.-C. Sheu. 2012. Enzyme production and growth of Aspergillus oryzae S. on soybean koji fermentation. APCBEE Procedia 2:57-61. https://doi.org/10.1016/j .apcbee.2012.06.011.

Church, D. C. 1993. The Ruminant Animal: Digestive Physiology and Nutrition. Waveland Press, Prospect Heights, IL.

CLSI. 2002. Reference Methods for Broth Dilution Antifungal Susceptibility Testing of Yeast: Approved Standard. National Committee for Clinical Laboratory Standards, Wayne, PA.

Coblentz, W. K., and M. G. Bertram. 2012. Effects of a propionic acid-based preservative on storage characteristics, nutritive value, and energy content for alfalfa hays packaged in large round bales. J. Dairy Sci. 95:340-352. https://doi.org/10.3168/jds.2011-4496.

Coblentz, W. K., K. P. Coffey, A. N. Young, and M. G. Bertram. 2013. Storage characteristics, nutritive value, energy content, and in vivo digestibility of moist, large rectangular bales of alfalfa-orchardgrass hay treated with a propionic acid-based preservative. J. Dairy Sci. 96:2521-2535. https://doi.org/10.3168/jds.2012-6145.

Coblentz, W. K., J. O. Fritz, K. K. Bolsen, and R. C. Cochran. 1996. Quality Changes in Alfalfa Hay During Storage in Bales. J. Dairy Sci. 79:873-885. https://doi.org/10.3168/jds.S0022-0302(96)76436 -6 .
Coblentz, W. K., and P. C. Hoffman. 2009. Effects of bale moisture and bale diameter on spontaneous heating, dry matter recovery, in vitro true digestibility, and in situ disappearance kinetics of alfalfaorchardgrass hays. J. Dairy Sci. 92:2853-2874. https://doi.org/10 $.3168 /$ jds.2008-1920.

Coblentz, W. K., and P. C. Hoffman. 2010. Effects of spontaneous heating on estimates of total digestible nutrients for alfalfaorchardgrass hays packaged in large round bales. J. Dairy Sci. 93:3377-3389. https://doi.org/10.3168/jds.2010-3133.

Coblentz, W. K., J. Turner, D. Scarbrough, K. Lesmeister, Z. Johnson, D. Kellogg, K. Coffey, L. McBeth, and J. Weyers. 2000. Storage characteristics and nutritive value changes in bermudagrass hay as affected by moisture content and density of rectangular bales. Contribution no. 99109 of the Arkansas Agric. Exp. Stn. 40:1375-1383.

Collins, M., and W. K. Coblentz. 2007. Post-harvest physiology of forages. Pages 583-600 in Forages, the Science of Grassland Agriculture. Volume II, 6th ed. R. F. Barnes, C. J. Nelson, K. J. Moore, and M. Collins, ed. Blackwell Publishing Professional, Ames, IA.

Corey, A. M., K. G. S. Wamsley, T. S. Winowiski, and J. S. Moritz. 2014. Effects of calcium lignosulfonate, mixer-added fat, and feed form on feed manufacture and broiler performance. J. Appl. Poult. Res. 23:418-428. https://doi.org/10.3382/japr.2013-00916.

Cui, C., R. Sun, and D. S. Argyropoulos. 2014. Fractional precipitation of softwood kraft lignin: Isolation of narrow fractions common to a variety of lignins. JACS Sustainable Chemistry Engineering 2:959-968. https://doi.org/10.1021/sc400545d.

Davidson, P. M., T. M. Taylor, and S. E. Schmidt. 2013. Chemical Preservatives and Natural Antimicrobial Compounds. Pages 765801 in Doyle M, Buchanan R, Food Microbiology. ASM Press, Washington, DC.

Davies, M. H., and I. B. Warboys. 1982. Evaluation of propionic acidtreated hay as a feed for growing sheep. Grass Forage Sci. 37:165167. https://doi.org/10.1111/j.1365-2494.1982.tb01593.x.

De Greef, J. A., and C. F. Van Sumere. 1966. Effect of phenolic aldehydes, coumarins and related compounds on the growth of Saccharomyces cerevisiae. Arch. Int. Physiol. Biochim. 74:512.

Deetz, D. A., J. H. Harrison, F. R. Valdez, and D. W. Evans. 1989. Impact of noncorrosive forage stabilizers on digestibility of alfalfa hay and lactation performance of dairy cows. J. Dairy Sci. 72:20622073. https://doi.org/10.3168/jds.S0022-0302(89)79330-9.

Dizhbite, T., G. Telysheva, V. Jurkjane, and U. Viesturs. 2004. Characterization of the radical scavenging activity of lignins-natural antioxidants. Bioresour. Technol. 95:309-317. https://doi.org/10 .1016/j.biortech.2004.02.024.

Dong, X., M. Dong, Y. Lu, A. Turley, T. Jin, and C. Wu. 2011. Antimicrobial and antioxidant activities of lignin from residue of corn stover to ethanol production. Ind. Crops Prod. 34:1629-1634. https://doi.org/10.1016/j.indcrop.2011.06.002.

Drackley, J. K. 1999. Biology of dairy cows during the transition period: The final frontier? J. Dairy Sci. 82:2259-2273. https://doi .org/10.3168/jds.S0022-0302(99)75474-3.

Druvefors, U. Ä., V. Passoth, and J. Schnürer. 2005. Nutrient effects on biocontrol of Penicillium roqueforti by Pichia anomala J121 during airtight storage of wheat. Appl. Environ. Microbiol. 71:1865-1869. https://doi.org/10.1128/AEM.71.4.1865-1869.2005.

DuBois, M., K. A. Gilles, J. K. Hamilton, P. Rebers, and F. Smith 1956. Colorimetric method for determination of sugars and related substances. J. Anal. Chem. 28:350-356. https://doi.org/10.1021/ ac60111a017.

Duval, A., S. Molina-Boisseau, and C. Chirat. 2015. Fractionation of lignosulfonates: Comparison of ultrafiltration and ethanol solubility to obtain a set of fractions with distinct properties. Holzforschung 69:127-134. https://doi.org/10.1515/hf-2014-0082.

EFSA. 2011. Scientific opinion on the safety and efficacy of propionic acid, sodium propionate, calcium propionate and ammonium propionate for all animal species. EFSA J. 9:2446.

FAO. 2008. Joint FAO/WHO Expert Committee on Food Additives. 69th Meeting. Compendium of food additive specifications. Food and Agriculture Organization, Rome, Italy.

Flickinger, E. A., J. M. Campbell, L. G. Schmitt, and G. C. Fahey Jr.. 1998. Selected lignosulfonate fractions affect growth performance, 
digestibility, and cecal and colonic properties in rats. J. Anim. Sci. 76:1626-1635. https://doi.org/10.2527/1998.7661626x.

García, A., G. Spigno, and J. Labidi. 2017. Antioxidant and biocide behaviour of lignin fractions from apple tree pruning residues. Ind. Crops Prod. 104:242-252. https://doi.org/10.1016/j.indcrop.2017 .04 .063 .

Glass, N. L., and G. C. Donaldson. 1995. Development of primer sets designed for use with the PCR to amplify conserved genes from filamentous ascomycetes. Appl. Environ. Microbiol. 61:1323-1330. https://doi.org/10.1128/AEM.61.4.1323-1330.1995.

Goering, H. K., and P. J. Van Soest. 1970. Forage fiber analysis. Apparatus, reagents, procedures and some applications. J. Agric Handbook 379:20.

Goodwin, P., and S. Annis. 1991. Rapid identification of genetic variation and pathotype of Leptosphaeria maculans by random amplified polymorphic DNA assay. Appl. Environ. Microbiol. 57:24822486. https://doi.org/10.1128/AEM.57.9.2482-2486.1991.

Gordts, S. C., G. Férir, T. D'huys, M. I. Petrova, S. Lebeer, R. Snoeck, G. Andrei, and D. Schols. 2015. The low-cost compound lignosulfonic acid (LA) exhibits broad-spectrum anti-HIV and anti-HSV activity and has potential for microbicidal applications. PLoS One 10:e0131219. https://doi.org/10.1371/journal.pone.0131219.

Górka, P., Z. Kowalski, P. Pietrzak, A. Kotunia, R. Kiljanczyk, J. Flaga, J. Holst, P. Guilloteau, and R. Zabielski. 2009. Effect of sodium butyrate supplementation in milk replacer and starter diet on rumen development in calves. J. Physiol. Pharmacol. 60:47-53.

Gosselink, R. J. A., E. de Jong, B. Guran, and A. Abächerli. 2004. Coordination network for lignin - standardisation, production and applications adapted to market requirements (EUROLIGNIN). Ind. Crops Prod. 20:121-129. https://doi.org/10.1016/j.indcrop .2004.04.015.

Guerrero, J. N., and W. S. Shenvood. 1997. Summertime storage of alfalfa hay in the irrigated sonoran desert affects hay quality. J. Prod. Agric. 10:495-501. https://doi.org/10.2134/jpa1997.0495.

Hall, M. B. 2003. Challenges with nonfiber carbohydrate methods. J. Anim. Sci. 81:3226-3232. https://doi.org/10.2527/2003 $.81123226 \mathrm{x}$.

Hall, M. B. 2015. Comparisons of in vitro fermentation and high moisture forage processing methods for determination of neutral detergent fiber digestibility. Anim. Feed Sci. Technol. 199:127-136. https://doi.org/10.1016/j.anifeedsci.2014.11.012.

Harstad, O. M., and E. Prestløkken. 2000. Effective rumen degradability and intestinal indigestibility of individual amino acids in solvent-extracted soybean meal (SBM) and xylose-treated SBM $\left(\right.$ SoyPass $\left.{ }^{\circledR}\right)$ determined in situ. Anim. Feed Sci. Technol. 83:31-47. https://doi.org/10.1016/S0377-8401(99)00114-5.

Hoskins, B. 1997. Soil testing handbook for professionals in agriculture, horticulture, nutrient and residuals management. Maine Agriculture and Forest Experimental Station.

Huang, X., and A. Madan. 1999. CAP3: A DNA Sequence Assembly Program. 9:868-877.

Hugo, W. 1992. Principles and Practice of Disinfection, Preservation and Sterilization. A. D. Russell, W. B. Hugo, and G. A. J. Ayliffe, ed. Blackwell Scientific Publications, Oxford, UK.

Hussein, H. S., R. M. Jordan, and M. D. Stern. 1991. Ruminal protein metabolism and intestinal amino acid utilization as affected by dietary protein and carbohydrate sources in sheep. J. Anim. Sci. 69:2134-2146. https://doi.org/10.2527/1991.6952134x.

Jha, A., and A. Kumar. 2018. Deciphering the role of sodium lignosulfonate against Candida spp. as persuasive anticandidal agent. Int. J. Biol. Macromolecules 107(Pt A):1212-1219.

Kamande, G., J. Baah, K.-J. Cheng, T. McAllister, and J. Shelford. 2000. Effects of Tween 60 and Tween 80 on protease activity, thiol group reactivity, protein adsorption, and cellulose degradation by rumen microbial enzymes. J. Dairy Sci. 83:536-542. https://doi .org/10.3168/jds.S0022-0302(00)74913-7.

Kaur, R., S. K. Uppal, and P. Sharma. 2017. Antioxidant and antibacterial activities of sugarcane bagasse lignin and chemically modified lignins. Sugar Tech 19:675-680. https://doi.org/10.1007/ s12355-017-0513-y.
Kim, S., M. M. Fernandes, T. Matamá, A. Loureiro, A. C. Gomes, and A. Cavaco-Paulo. 2013. Chitosan-lignosulfonates sono-chemically prepared nanoparticles: Characterisation and potential applications. Colloids Surf. B Biointerfaces 103:1-8. https://doi.org/10 .1016/j.colsurfb.2012.10.033.

Knapp, W. R., D. A. Holt, and V. L. Lechtenberg. 1976. Propionic acid as hay preservative. Agron. J. 68:120-123. https://doi.org/10 .2134/agronj1976.00021962006800010031x.

Lacey, J., and K. Lord. 1977. Methods for testing chemical additives to prevent moulding of hay. Ann. Appl. Biol. 87:327-335. https:// doi.org/10.1111/j.1744-7348.1977.tb01897.x.

Lacey, J., K. A. Lord, H. G. C. King, and R. Manlove. 1978. Preservation of baled hay with propionic and formic acids and a proprietary additive. Ann. Appl. Biol. 88:65-73. https://doi.org/10.1111/ j.1744-7348.1978.tb00680.x.

Li, W. R., H.-L. Li, Q.-S. Shi, T.-L. Sun, X.-B. Xie, B. Song, and X.-M. Huang. 2016. The dynamics and mechanism of the antimicrobial activity of tea tree oil against bacteria and fungi. Appl Microbiol. Biotechnol. 100:8865-8875. https://doi.org/10.1007/ s00253-016-7692-4.

Lück, E., and M. Jager. 1997. Antimicrobial Food Additives: Characteristics, Uses, Effects. Vol. 2. Springer Science \& Business Media, Berlin, Germany.

Magan, N., and D. Aldred. 2007. Post-harvest control strategies: Minimizing mycotoxins in the food chain. Int. J. Food Microbiol. 119:131-139. https://doi.org/10.1016/j.ijfoodmicro.2007.07.034.

Malloch, D. 1981. Moulds, their isolation, cultivation, and identification. University of Toronto Press, Toronto, Canada.

McBeth, L. J., K. P. Coffey, W. K. Coblentz, J. E. Turner, D. A. Scarbrough, C. R. Bailey, and M. R. Stivarius. 2001. Impact of heating-degree-day accumulation during bermudagrass hay storage on nutrient utilization by lambs. J. Anim. Sci. 79:2698-2703. https://doi.org/10.2527/2001.79102698x.

McDonald, P., A. Henderson, and S. Heron. 1991. The Biochemistry of Silage. Chalcombe Publications, Aberystwyth, UK.

Merianos, J. 1991. Quarternary ammonium antimicrobial compounds. J. Disinfection Sterilization Preservation 225-255.

Mertens, D. R. 1977. Dietary fiber components: relationship to the rate and extent of ruminal digestion. Fed. Proc. 36:187-192.

Mertens, D. R. 2003. Challenges in measuring insoluble dietary fiber. J. Anim. Sci. 81:3233-3249. https://doi.org/10.2527/2003 $.81123233 x$.

Mohammed, R., S. M. McGinn, and K. A. Beauchemin. 2011. Prediction of enteric methane output from milk fatty acid concentrations and rumen fermentation parameters in dairy cows fed sunflower, flax, or canola seeds. J. Dairy Sci. 94:6057-6068. https://doi.org/ 10.3168/jds.2011-4369.

Mohanty, G. P., N. A. Jorgensen, R. M. Luther, and H. H. Voelker. 1969. Effect of molded alfalfa hay on rumen activity, performance, and digestibility in dairy steers. J. Dairy Sci. 52:79-83. https://doi .org/10.3168/jds.S0022-0302(69)86505-7.

Montgomery, M., A. Tineo, B. Bledsoe, and H. Baxter. 1986. Effect of moisture content at baling on nutritive value of alfalfa orchardgrass hay in conventional and large round bales. J. Dairy Sci 69:1847-1853. https://doi.org/10.3168/jds.S0022-0302(86)80610 $-5$.

Müller, C. E., C. Hultén, and G. Gröndahl. 2011. Assessment of hygienic quality of haylage fed to healthy horses. Grass Forage Sci. 66:453-463. https://doi.org/10.1111/j.1365-2494.2011.00803.x.

NASS. 2019a. Crop Values 2018 Summary. USDA, Washington, DC.

NASS. 2019b. Crop Production 2018 Summary. USDA, Washington, DC.

Negm, N. A., and S. M. Tawfik. 2014. Characterization, surface properties and biological activity of some synthesized anionic surfactants. J. Ind. Eng. Chem. 20:4463-4472. https://doi.org/10.1016/ j.jiec.2014.02.018.

Núñez-Flores, R., B. Giménez, F. Fernández-Martín, M. E. LópezCaballero, M. P. Montero, and M. C. Gómez-Guillén. 2012. Role of lignosulphonate in properties of fish gelatin films. Food Hydrocoll. 27:60-71. https://doi.org/10.1016/j.foodhyd.2011.08.015. 
O'Donnell, K. 1993. Fusarium and its near relatives. Pages 225-233 in The Fungal Holomorph: Mitotic, Meiotic and Pleomorphic Speciation in Fungal Systematics. D. R. Reynolds and J. W. Taylor, ed. CAB International, Wallingford, UK.

Oba, M., and M. S. Allen. 1999. Evaluation of the importance of the digestibility of neutral detergent fiber from forage: Effects on dry matter intake and milk yield of dairy cows. J. Dairy Sci. 82:589596. https://doi.org/10.3168/jds.S0022-0302(99)75271-9.

Owens, F. N., and M. Basalan. 2016. Ruminal Fermentation. Pages 63-102 in Rumenology. D. D. Millen, M. De Beni Arrigoni, and R. D. Lauritano Pacheco, ed. Springer International Publishing, Cham.

Piyasena, P., E. Mohareb, and R. McKellar. 2003. Inactivation of microbes using ultrasound: A review. Int. J. Food Microbiol. 87:207216. https://doi.org/10.1016/S0168-1605(03)00075-8.

Rees, D. V. H. 1982. A discussion of sources of dry matter loss during the process of haymaking. J. Agric. Eng. 27:469-479. https://doi .org/10.1016/0021-8634(82)90085-3.

Rex, J. H., B. Alexander, D. Andes, B. Arthington-Skaggs, S. Brown, V. Chaturveli, A. Espinel-Ingroff, M. Ghannoum, C. Knapp, and M. Motyl. 2008. Reference method for broth dilution antifungal susceptibility testing of filamentous fungi: Approved standard. National Committee for Clinical Laboratory Standards, Wayne, PA.

Ringena, O., B. Saake, and R. Lehnen. 2005. Isolation and fractionation of lignosulfonates by amine extraction and ultrafiltration: A comparative study. Holzforschung 59:405-412. https://doi.org/10 $.1515 /$ HF.2005.066.

Roberts, C. A. 1995. Microbiology of stored forages. Post-harvest physiology preservation of forages. Pages 21-38 in Post-Harvest Physiology Preservation of Forages. Crop Science Society of America Special Publications, Minneapolis, MN.

Rotz, C. A. 2003. How to maintain forage quality during harvest and storage. Pages 227-236 in Proc. Western Canadian Dairy Seminar, Edmonton, AB, Canada.

Rotz, C. A., and R. E. Muck. 1994. Changes in forage quality during harvest and storage. Pages 828-868 in Forage Quality, Evaluation, and Utilization. G. C. Fahey Jr., M. Collins, D. R. Mertens, and L. E. Moser, ed. Am. Soc. Agron., Madison, WI.

Russell, J. R., S. J. Yoder, and S. J. Marley. 1990. The effects of bale density, type of binding and storage surface on the chemical composition, nutrient recovery and digestibility of large round hay bales. Anim. Feed Sci. Technol. 29:131-145. https://doi.org/ 10.1016/0377-8401(90)90099-T.

Sanger, F., S. Nicklen, and A. R. Coulson. 1977. DNA sequencing with chain-terminating inhibitors. Proc. Natl. Acad. Sci. USA 74:54635467. https://doi.org/10.1073/pnas.74.12.5463.

Schroeder, G., L. Erasmus, K. J. Leeuw, and H. H. Meissner. 1996. The use of acid detergent insoluble nitrogen to predict digestibility of rumen undegradable protein of heat processed plant proteins. S. Afr. J. Anim. Sci. 26:49-52.

Shinners, K. 2010. Baleage - The Dry Hay Alternative. Forage Focus, Equipment. December 2010.

Siegfried, V. R., H. Ruckemann, and G. Stumpf. 1984. Eine HPLCMethode zur Bestimmung organischer Sauren in Silagen. Landwirtsch Forsch. 37:298-304.

Singleton, V., and J. Rossi. 1965. Colorimetry of total phenolics with phosphomolybdic-phosphotungstic acid reagents. Am. J. Enol. Vitic. 16:416-417.

Stanford, K., T. McAllister, Z. Xu, K.-J. Cheng, and M. Pickard. 1995. Comparison of lignosulfonate-treated canola meal and soybean meal as rumen undegradable protein supplements for lambs. Can. J. Anim. Sci. 75:371-377. https://doi.org/10.4141/cjas95-056.
Tawfik, S. M., M. Zaky, G. M. Mohammad, and A. E. Attia. 2015. Synthesis, characterization, and in vitro antifungal activity of anionic and nonionic surfactants against crop pathogenic fungi. J. Ind. Eng. Chem. 29:163-171. https://doi.org/10.1016/j.jiec.2015 .03 .031 .

Tomani, P. 2010. The Lignoboost process. Cellul. Chem. Technol. 44:53-58.

Turner, J. E., W. K. Coblentz, D. A. Scarbrough, K. P. Coffey, D. W. Kellogg, L. J. McBeth, and R. T. Rhein. 2002. Changes in nutritive value of bermudagrass hay during storage. Contrib. no. 00121 of the Arkansas Agric. Exp. Stn. 94:109-117.

Vale-Silva, L., M.-J. Silva, D. Oliveira, M.-J. Gonçalves, C. Cavaleiro, L. Salgueiro, and E. Pinto. 2012. Correlation of the chemical composition of essential oils from Origanum vulgare ssp. virens with their in vitro activity against pathogenic yeasts and filamentous fungi. J. Med. Microbiol. 61:252-260. https://doi.org/10.1099/ jmm.0.036988-0.

Van Soest, P. J., J. B. Robertson, and B. A. Lewis. 1991. Methods for dietary fiber, neutral detergent fiber, and nonstarch polysaccharides in relation to animal nutrition. J. Dairy Sci. 74:3583-3597. https://doi.org/10.3168/jds.S0022-0302(91)78551-2.

Wang, Y., T. Marx, J. Lora, L. E. Phillip, and T. A. McAllister. 2009. Effects of purified lignin on in vitro ruminal fermentation and growth performance, carcass traits and fecal shedding of Escherichia coli by feedlot lambs. Anim. Feed Sci. Technol. 151:21-31. https://doi.org/10.1016/j.anifeedsci.2008.11.002.

Weatherburn, M. 1967. Phenol-hypochlorite reaction for determination of ammonia. J. Anal. Chem. 39:971-974. https://doi.org/10 $.1021 /$ ac60252a045.

White, T. J., T. Bruns, S. Lee, and J. Taylor. 1990. Amplification and direct sequencing of fungal ribosomal RNA genes for phylogenetics. In PCR protocols: A guide to methods and applications. M. A. Innis, D. H. Gelfand, J. J. Sninsky, and T. J. White, ed. Academic, New York, NY. 18:315-322.

Windschitl, P. M., and M. D. Stern. 1988. Evaluation of calcium lignosulfonate-treated soybean meal as a source of rumen protected protein for dairy cattle. J. Dairy Sci. 71:3310-3322. https://doi .org/10.3168/jds.S0022-0302(88)79936-1.

Wright, C. F., M. A. G. von Keyserlingk, M. L. Swift, L. J. Fisher, J. A. Shelford, and N. E. Dinn. 2005. Heat- and lignosulfonatetreated canola meal as a source of ruminal undegradable protein for lactating dairy cows. J. Dairy Sci. 88:238-243. https://doi.org/ 10.3168/jds.S0022-0302(05)72681-3.

Wu, C., F. Chen, X. Wang, H. Kim, G. He, V. Haley-Zitlin, and G. Huang. 2006. Antioxidant constituents in feverfew (Tanacetum parthenium) extract and their chromatographic quantification. Food Chem. 96:220-227. https://doi.org/10.1016/j.foodchem.2005 .02 .024 .

Yang, W., E. Fortunati, D. Gao, G. M. Balestra, G. Giovanale, X. He, L. Torre, J. M. Kenny, and D. Puglia. 2018. Valorization of acid isolated high yield lignin nanoparticles as innovative antioxidant/antimicrobial organic materials. ACS Sustain. Chem.\& Eng. 6:3502-3514. https://doi.org/10.1021/acssuschemeng.7b03782.

Yun, J., and D. G. Lee. 2016. A novel fungal killing mechanism of propionic acid. FEMS Yeast Res. 16:fow089. https://doi.org/10 $.1093 /$ femsyr/fow089.

Ziemer, C. J., A. J. Heinrichs, C. J. Canale, and G. A. Varga. 1991. Chemical drying agents for alfalfa hay: Effect on nutrient digestibility and lactational performance. J. Dairy Sci. 74:2674-2680. https://doi.org/10.3168/jds.S0022-0302(91)78445-2. 